OPEN ACCESS

Edited by:

Mandeep Kaur:

University of the Witwatersrand,

South Africa

Reviewed by:

Shuangyu LV,

Henan University, China

Lucia Taja-Chayeb,

National Institute of Cancer (INCan),

Mexico

${ }^{*}$ Correspondence:

Chandi C. Mandal

chandicmanda/@gmail.com;

ccmandal@curaj.ac.in

Specialty section:

This article was submitted to Human and Medical Genomics,

a section of the journal

Frontiers in Genetics

Received: 12 June 2021

Accepted: 23 August 2021

Published: 16 September 2021

Citation:

Kumar N and Mandal CC (2021) Cholesterol-Lowering Drugs on Akt

Signaling for Prevention

of Tumorigenesis.

Front. Genet. 12:724149.

doi: 10.3389/fgene.2021.724149

\section{Cholesterol-Lowering Drugs on Akt Signaling for Prevention of Tumorigenesis}

\author{
Navneet Kumar ${ }^{1}$ and Chandi C. Mandal2* \\ ' Department of Biochemistry, All India Institute of Medical Sciences, Bhopal, India, ${ }^{2}$ Department of Biochemistry, School of \\ Life Sciences, Central University of Rajasthan, Ajmer, India
}

Cholesterol has been reported to be accumulated in cancer cells. The metabolic dysregulation of the cholesterol is associated with tumor development and progression. The cholesterol-lowering drugs have been found to be involved in the prevention and treatment of various cancers. Akt, a serine/threonine kinase, can modulate the role of several downstream proteins involved in cell proliferation, migration, invasion, metabolism, and apoptosis. Since its involvement in several signaling pathways, its dysregulation is commonly reported in several cancers. Thus, targeting Akt could be an effective approach for cancer prevention and therapy. Cholesterol-lowering drugs have been found to affect the expression of Akt, and its activation in the cancer cells and thus have shown anticancer activity in different type of cancers. These drugs act on various signaling pathways such as PTEN/Akt, PI3k/Akt, Akt/NF-kB, Akt/FOXO1, Akt/mTOR, etc., which will be discussed in this article. This review article will discuss the significance of cholesterol in cancer cells, cholesterol-lowering drugs, the role of Akt in cancer cells, and the effects of cholesterol-lowering drugs on Akt in the prevention of therapy resistance and metastasis.

Keywords: cholesterol, cholesterol-lowering drugs, Akt signaling, cancer, statins, fenofibrate

\section{INTRODUCTION}

Cholesterol, a 27-carbon molecule, is distributed throughout the human body and shows a vital role in the cell membrane, nerve conduction, steroid hormone synthesis, vitamin D synthesis, and many more. Diet is having a significant amount of cholesterol which is absorbed in the gastrointestinal tract with the help of bile salts and the involvement of NPC1L1 (a cholesterol transporter), NUMB (a clathrin adaptor), and LIMA1 (an adaptor protein) (Altmann et al., 2004; Goldstein and Brown, 2009; Li et al., 2014). It can also be synthesized de novo by almost all cells of the body. Beyond de novo synthesis, cells also take up the cholesterol from low-density lipoprotein (LDL) present in the circulation by LDL-receptor mediated endocytosis (Goldstein and Brown, 2009). A balance between cholesterol synthesis and intestinal absorption is critically important for maintaining the cholesterol level in the body. Excess cholesterol is balanced by reverse cholesterol transport to the liver for biliary elimination (Tall et al., 2001; Brewer and Santamarina-Fojo, 2003). Transcriptional regulator sterol regulatory element-binding protein-2 (SREBP-2) and liver $\mathrm{X}$ receptors are the critical regulators for maintaining cholesterol homeostasis. The cholesterol homeostasis is maintained by the cholesterol level in the endoplasmic reticulum. When cholesterol level is low in the endoplasmic reticulum, SREBP-2 translocates to the nucleus 
from the endoplasmic reticulum via Golgi. It leads to the expression of genes responsible for cholesterol synthesis and uptake from outside (Ikonen, 2008). Excess of cholesterol, termed hypercholesterolemia, leads to atherosclerosis, where arteries become narrow down and then blocked, leading to slowing down or blocking of the blood flow to vital organs. It has also been reported that elevated cholesterol also deteriorates bone health (Mandal, 2015).

\section{CHOLESTEROL IN CANCER CELLS}

In 1909, it was first observed that cholesterol is deposited in the cells of the malignant tissues (White, 1909). A number of epidemiological and basic studies have shown the association between high cholesterol and increased risk of cancer (Mandal and Rahman, 2014; Mandal, 2015; Mandal et al., 2016). It is now known that cholesterol helps cancer cells in proliferation, migration, invasion and epithelial to mesenchymal transition (EMT) (Liu Z. et al., 2018; Sharma et al., 2019; Wang et al., 2019; Huang et al., 2020; Bandyopadhayaya et al., 2021; Patel and Kashfi, 2021). Highly proliferating cancer cells need a continuous supply of cholesterol for membrane biogenesis and numerous other functions of the cells. Thus, cholesterol import, its biosynthesis, and its export all are modulated in cancer cells. Multiple mechanisms promote deregulation of cholesterol homeostasis and lead to cancer development (Smith and Land, 2012; Yun et al., 2014; Vassilev et al., 2015; Jun et al., 2020; Chan et al., 2021). The transcriptional controller of cholesterol biosynthesis SREBP1 and 2 are elevated in various cancers (Li et al., 2016; Jie et al., 2019; Sharma et al., 2019). There are several oncogenic signals also which are known to modulate the cholesterol synthesis in cancer cells. Constitutive expression of oncogenic PI3K/Akt pathway is one of them which activate SREBP and increase the synthesis of cholesterol. It also induces LDL-R mediated cholesterol import and inhibits ABCA-1 facilitated cholesterol export (Porstmann et al., 2008; Dong et al., 2014). In hepatocellular carcinoma, Akt-mediated activation of phosphoenolpyruvate carboxykinase 1 (PCK-1) activates SREBP proteins and promotes tumor cell proliferation (Xu et al., 2020). In prostate cancer, Akt leads to elevated intracellular cholesterol levels and encourages cancer aggressiveness and bone metastasis (Thysell et al., 2010; Yue et al., 2014). Akt/mTORC1/SREBP pathway promotes cell growth by elevating cholesterol synthesis (Porstmann et al., 2008). By co-operating at multiple levels, the Hippo and p53 signaling pathways regulate cholesterol levels by controlling SREBP activity (Aylon and Oren, 2016). Mitochondrial cholesterol is reported to be elevated in several cancer types. Its import into mitochondria is regulated by StAR protein (Christenson and Strauss, 2000). In hepatocellular carcinoma, elevated StAR protein was linked with the increased cholesterol levels, and its knockdown effectively augmented the sensitivity of cancer cells toward chemotherapeutic agents (Montero et al., 2008). In colon cancer, ABC1 pump, which is involved in pumping out the cholesterol from mitochondria, expression inhibition by oncogenic mutations or loss of function mutation is associated with raised mitochondrial cholesterol levels. This elevation of cholesterol level leads to inhibition of apoptosis and increases cancer cell survival (Smith and Land, 2012).

Other than cholesterol metabolism deregulation and mitochondrial cholesterol accumulation, cholesterol metabolites are also linked with various cancers. One of the cholesterol metabolites, i.e., steroid hormone estrogen, is established in cancer development (Hsu et al., 2017; Rodriguez et al., 2019). Overall, cholesterol accumulation is one of the hallmarks of cancer development and its progression.

\section{CHOLESTEROL-LOWERING DRUGS}

Hypercholesterolemia is a condition of too much non-HDL cholesterol in the blood, increasing fat deposits in the arteries, and the risk of blockages. Long-term exposure to hypercholesterolemia can lead to atherosclerosis, resulting in cardiovascular disease (Śliż et al., 2019). Cholesterol-lowering drugs are the established tools to control hypercholesterolemia and cardiovascular disease (Reiner et al., 2011). Several in vitro, in vivo, and clinical trial studies have shown that these drugs also have promising roles in cancer treatment (Giacomini et al., 2021). The currently used cholesterol-lowering drugs are statins, citrate lyase inhibitors, fibrates, bile acid sequestrants, and selective cholesterol absorption inhibitors (Catapano et al., 2016). Statins are the 3-hydroxy-3-methyl-glutaryl-coenzyme A reductase (HMG-CoA reductase) inhibitors, a key enzyme in synthesizing cholesterol (Alberts, 1988). The approved statins for lowering the cholesterol level by the United States are fungi-derivedlovastatin, pravastatin, simvastatin, and synthetically derivedrosuvastatin, atorvastatin, fluvastatin, pitavastatin. The central role of statins is to lower the LDL-C level, and the maximum efficacy of reducing the LDL-C by $60 \%$ has been reported in rosuvastatin (Feingold, 2000). Other than LDL-C, statins can also lower triglyceride and VLDL levels and control hyperlipidemia (Stein et al., 1998; Feingold, 2000). Other than cholesterollowering properties, statins show pleiotropic effects also. For example, statins can reduce the C-reactive protein level and offer an anti-inflammatory effect (Joshi and Jacobson, 2010). They also provide anti-proliferative properties, antioxidant properties and attenuate vascular remodeling (Liao, 2005). Several scientific reports have shown the correlation between statins and cancer cells. In cancer cells, statins reduce proliferation, migration, and invasion (Di Bello et al., 2020). They can minimize cancer's negative consequences and increase the survival time (Gupta et al., 2019). Ezetimibe, a cholesterol absorption inhibitor, impedes cholesterol absorption in the intestine and helps to reduce LDL-C levels (Bruckert et al., 2003). This drug is typically used in combination with statins as it is less effective in lowering the cholesterol level alone (Feingold, 2000). Ezetimibe also shows the anti-tumor effects by inhibiting angiogenesis, as shown for the hepatic tumors of $\operatorname{Pten}^{\Delta \text { hep }}$ mice with hypercholesterolemia (Miura et al., 2019). Bempedoic acid, a citrate lyase inhibitor, is another cholesterol-lowering drug and can inhibit adenosine triphosphate-citrate lyase (ACLY), catalyzing the formation of 
acetyl-CoA in the cytoplasm. It can reduce non-HDL-C, LDLC, and apolipoprotein B (Laufs et al., 2019). ACLY plays a decisive role in cancer metabolism. It provides the acetyl CoA in lipid synthesis, aspartate production (required for nucleotide), and NADPH production for biosynthesis purposes (Icard et al., 2020). Inhibition of it by bempedoic acid might be crucial to show its anti-cancerous effects. Fenofibrate comes under the fibrate category of cholesterol-lowering drugs, which are used to treat hyperlipidemia and hypercholesterolemia. Fenofibrate activates peroxisome proliferator-activated receptors $\alpha(\operatorname{PPAR} \alpha)$, a transcription factor that stimulates the beta-oxidation of fatty acids (Schoonjans et al., 1996). It has been found to reduce cellular proliferation and boost apoptosis in cancer cells (Yamasaki et al., 2011; Sun et al., 2019). Since cholesterollowering drugs can modulate proliferation, migration, and invasion and inhibit tumorigenesis, this review article will discuss the effects of these drugs in correlation with Akt signaling.

\section{Akt SIGNALING AND CANCER}

Akt, also known as Protein kinase B, is a serine/threonine kinase. On phosphorylation, it converts into Phospho-Akt, an active form of Akt that acts on its downstream targets. There are three isoforms of the Akt gene, i.e., Akt1, Akt2, and Akt3, and principally it is Akt1 isoform (Datta et al., 1999). They differentially act in normal cells and cancer cells (Bellacosa et al., 1993). Once survival factors activate Akt, it translocates to the plasma membrane, gets phosphorylate, and activates the downstream targets. Various growth factors such as insulinlike growth factor, vascular endothelial growth factor, epidermal growth factor, platelet-derived growth factor (PDGF), and other factors such as cytokines, cAMP, hypoxia can induce the kinase activity of the Akt (Datta et al., 1999).

Akt acts as a potential oncogenic molecule and is highly expressed and activated in an extensive range of human cancers (Cerami et al., 2012; Galbraith et al., 2021; Sun et al., 2021). Oncogenic property of Akt by amplification and overexpression is more commonly found in cancers like gastric, glioblastoma, ovarian, breast, pancreatic, prostate, etc. (Staal, 1987; Bellacosa et al., 1995; Cheng et al., 1996; Nakatani et al., 1999; Knobbe and Reifenberger, 2003). Mutation in Akt is not very common as compared to amplification and overexpression. The most frequent Akt mutation is found in its $\mathrm{PH}$ (pleckstrin homology) domain identified in cancers such as bladder, lung, pancreatic, endometrial, and urothelial (Malanga et al., 2008; Mohamedali et al., 2008; Shoji et al., 2009; Zilberman et al., 2009; Askham et al., 2010). The oncogenic role of Akt can also be displayed by mutations in upstream/downstream molecules such as PI3K, Ras, PTEN, and p27 (Downward, 2003; Mandal et al., 2012). Regulatory changes by $N^{6}$-methyladenosine $\left(\mathrm{m}^{6} \mathrm{~A}\right)$ methylation can also activate Akt signaling and increase proliferation, progression, migration, and invasion of cancer cells (Liu J. et al., 2018; Li et al., 2020; Shi et al., 2020). Post-translational modifications such as tyrosine phosphorylation, lysine modifications, ubiquitination, sumoylation, and acetylation are also important to hyperactivate
Akt in cancer cells which leads to tumorigenesis (Chan et al., 2012, 2014; Han et al., 2018).

Akt is a crucial regulator in signaling pathways for cell survival, insulin signaling, angiogenesis, and tumorigenesis (Revathidevi and Munirajan, 2019). It can up-regulate the cell cycle by promoting PCNA, CDK1, and Telomerase Reverse Transcriptase (Koundouros and Poulogiannis, 2018; Zhang and $\mathrm{Hu}, 2018$ ). It can activate cellular proliferation by phosphorylating tumor suppressor p21 which can arrest the cell cycle by constraining cyclin-CDK complexes (Zhou et al., 2001). Akt also shows the anti-apoptotic activity by regulating the members of the BCL-2 family of proteins. It can control apoptosis through inhibition of BIM (BCL-2-like protein 11), BAD (BCL-2/Bcl-XL-antagonist, causing cell death), caspase 9, and FoxO1 (forkhead box protein O1) (Sangawa et al., 2014; Kizilboga et al., 2019; Revathidevi and Munirajan, 2019; Wu et al., 2019). Akt exerts its effects on glucose metabolism, which is required for rapidly proliferating cells. It promotes Glut1 and Glut4 to the cell membrane and increases glucose transport (Kohn et al., 1996). It also encourages glycolytic enzymes such as hexokinase, phosphofructokinase (PFK)-1, and PFK-2 (Deprez et al., 1997; Gottlob et al., 2001). These metabolic changes in glucose metabolism endorse cell survival. Akt facilitates all these effects via regulating glycogen synthase kinase - 3 (GSK-3), a key controller for phosphorylation of the glycolytic enzymes (Datta et al., 1999). Lipogenesis is a crucial aspect of cancer cell proliferation and signaling (Koundouros and Poulogiannis, 2020). Activation of Akt promotes lipogenesis by providing metabolic intermediates of carbon for anabolism and reducing equivalents in the form of NADPH (Ward and Thompson, 2012). It increases acetyl-CoA synthesis required for lipogenesis by phosphorylating and activating the ATP citrate lyase (ACLY) (Berwick et al., 2002). Akt is a potential activator of mTORC1, which promotes de novo lipogenesis on phosphorylation (Porstmann et al., 2008; Saxton and Sabatini, 2017). SREBP-1 is one of the primary transcriptional regulators for lipogenesis. Akt averts the degradation of mature SREBP-1 and promotes lipogenesis. Since Akt is a vital molecule in cancer and is involved in various oncogenic signaling, this review article emphasizes the connection between cholesterol-lowering drugs and cancer prevention via Akt signaling. However, PI3K/Akt signaling is also crucial for various physiological and pathological functions like bone remodeling, cellular hypertrophy and cell differentiation (Mandal et al., 2009; Das et al., 2012; GhoshChoudhury et al., 2013; Mandal et al., 2016).

\section{CHOLESTEROL-LOWERING DRUGS ON Akt SIGNALING}

Cholesterol-lowering drugs have been stated to show antitumorigenic properties. They may act on HMG-CoA reductase and reduce the cholesterol level, which disturbs the cancer cells' lipid rafts and affects the cells' signaling (Lee E.J. et al., 2014). These drugs also inhibit various signaling pathways and halt cell proliferation, migration and metastatic activity, and encourage apoptosis in cancer cells (Klawitter et al., 2010; 
Mehta et al., 2017). One of the important signaling which have been found commonly involved in the mode of action of cholesterol-lowering drugs is Akt signaling (Ghosh-Choudhury et al., 2010; Mandal et al., 2011). This review explores the involvement of Akt signaling as a target of cholesterol-lowering drugs to inhibit different types of cancers.

\section{Lung Cancer}

Lung cancer has the highest incidence worldwide and stands at second for its mortality rate (Globocan, 2020). Non-smallcell lung carcinoma (NSCLC) shares $85 \%$ of all lung cancer and is insensitive toward cytotoxic chemotherapy (Chen et al., 2014; Hu et al., 2020). In lung cancer, unusual overexpression or stimulation of Akt has been observed, linked with elevated cancer cell proliferation and survival (Song et al., 2019). Simvastatin has been observed to lessen the expression of p-Akt in NSCLC derived A459 lung cancer cells (Hwang et al., 2011). Aktmediated survival pathway stimulates survivin synthesis, which may inhibit apoptosis in numerous cancer cell lines (Fornaro et al., 2003; Ohashi et al., 2004). Thus, p-Akt inhibition in A459 cells was found to down-regulate the survivin and increase apoptosis, as supported by the reported cleavage of PARP (Hwang et al., 2011). Simvastatin in blend with non-steroidal antiinflammatory drug sulindac showed synergistic effects on Akt signaling-dependent down-regulation of survivin and elevation of apoptosis in A549 cells (Kim et al., 2015). Lovastatin also shows anti-tumorigenic activity against lung cancer. In A549 cells, lovastatin selectively inhibited the pro-survival pathway of Akt (Sanli et al., 2011). A549 cells have a point mutation in the $\mathrm{K}$-Ras gene, triggering the PI3K/Akt pathway (Okudela et al., 2004). Activated Akt can activate ACLY by phosphorylating it (Berwick et al., 2002). Growth factors lead to the stimulation of PI3K/Akt, which increases the activity of ACLY via Aktmediated ACLY phosphorylation. ACLY promotes tumor growth in glycolytic tumors, and its inhibition is responsible for the halt in tumor growth and leads to the differentiation of tumor cells (Hatzivassiliou et al., 2005). Hanai et al. (2012) reported that inhibition of PI3k/Akt along with ACLY inhibition led to the enhanced anti-tumor effects of ACLY inhibition. Lovastatin is reported to show anti-tumor effects by diminishing the activity of ACLY via inhibition of Akt in lung cancer (Hanai et al., 2012). Akt is a well-known facilitator of radiation resistance in several cancer cells (Gupta et al., 2002). In A549 cells, the EGFR-PI3k-Akt pathway activation confers radio-resistance (Toulany et al., 2005; Sanli et al., 2011). Lovastatin effectively inhibited the ionizing radiations-induced Akt activation and stimulated activation of AMPK, which led to apoptosis of cancer cells and radiation sensitization (Sanli et al., 2011). AMPK is an AMP-activated kinase that can dephosphorylate and inhibit Akt (Kim et al., 2009) and work synergistically with lovastatin to radio-sensitize cancer cells. Braf/MEK/ERK1/2 cascade facilitates cell proliferation and apoptosis. This cascade can lead to many cancers, including lung cancer (Smalley and Smalley, 2018; Wang Q. et al., 2018; Zhang et al., 2019). Fluvastatin, a synthetic HMG-CoA reductase inhibitor, suppresses Akt and Braf/MEK/ERK1/2 pathways. This suppression leads to the inhibition of NSCLC by preventing cell growth and promoting apoptosis in vitro and in vivo
(Zhang et al., 2019). These studies show how statins inhibit lung cancer via Akt and how Akt can be a crucial target for chemotherapeutic purposes.

\section{Breast Cancer}

Breast cancer is the most reported cancer worldwide and fifth in all cancer deaths (Globocan, 2020). Women with elevated cholesterol have shown high incidences of breast cancer. The mevalonate pathway is the crucial pathway responsible for cholesterol synthesis (Kitahara et al., 2011). The products of the mevalonate pathway are known to promote proliferation, migration, and differentiation of tumor cells (Dimitroulakos et al., 2006). For example, isoprenoid activates Ras and Rho GTPase prenylation, leading to the stimulation of the PI3K/Akt pathway and promoting tumorigenesis (Schieber and Chandel, 2014). Thus, statins here can act like cancerstatic agents that inhibit the mevalonate pathway and inhibit cancer cell growth (Schointuch et al., 2014; Cardwell et al., 2015). In a study by Beckwitt et al. (2018) Akt phosphorylation was decreased by treatment of atorvastatin in three breast cancer cell lines, i.e., MCF-7 RFP, MDA-MB-231 RFP, and MDA-MB-231 RFP/Ecad, and this inhibition was shown even after stimulation with growth factor EGF. It indicates that atorvastatin can inhibit the phosphorylation of Akt even after growth factor stimulation and impede breast cancer cell growth (Beckwitt et al., 2018). In breast cancer, constitutive expression of MAPK/ERK and $\mathrm{PI} 3 \mathrm{~K} / \mathrm{Akt} / \mathrm{mTOR}$ signal pathways are significant events that promote cancer cell growth, survival, and metastasis (Downward, 2003; Engelman, 2009). Simvastatin treatment induces apoptosis, inhibits proliferation, suppresses these two pathways, and shows its anti-tumor effects in breast cancer (Wang et al., 2016). The inhibitory effect of simvastatin on phosphorylation of Akt has been detected in MDA-MB-231 xenograft breast tumor model also which led to the repression of antiapoptotic BCLXL expression and promotion of proapoptotic/antiproliferative proteins (Ghosh-Choudhury et al., 2010). Another Akt pathway, i.e., PTEN/Akt pathway, regulates multiple cellular dysfunctions in breast cancer cells, such as proliferation, metabolism, and genomic stability (Mehta et al., 2017). Atorvastatin has been found to increase the PTEN and decrease p-Akt in breast cancer cells and inhibit the PTEN/Akt pathway. The inhibition of the PTEN/Akt pathway by atorvastatin is reported to happen via increasing the expression of RhoB in breast cancer cells (Ma et al., 2019). RhoB is a Ras family member and regulates actin stress fibers and vesicle trafficking (Prendergast, 2001). In cancer cells, it acts as a tumor suppressor gene as it prevents cell proliferation and migration and encourages apoptosis by impeding PTEN/Akt pathway (Jiang et al., 2004). Dephosphorylation of Akt and increased expression of PTEN by statin treatment is also reported to suppress PI3K/Akt/mTOR pathway in ER-positive (MCF-7, T47D) as well as ER-negative (MDA-MB-231) breast cancer cells (Wang et al., 2016). Simvastatin treatment on Triplenegative breast cancer has shown decreased p-Akt and increased expression of PTEN, which led to reduced cell viability (Park et al., 2013). Lovastatin shows similar effects on p-Akt and PTEN in PTEN-expressing MDA-MB-231 cell lines, as demonstrated 
by atorvastatin and simvastatin (Klawitter et al., 2010). DJ1 is an oncogene associated with $\mathrm{H}$-Ras and increases cell proliferation and resistance to cell cycle arrest (Nagakubo et al., 1997). The overexpression of this oncogene is positively linked with p-Akt and poor prognosis of breast cancer (Kim et al., 2005). Klawitter et al. (2010) have shown that lovastatin-led PTEN expression caused the reduction in the expression of DJ-1, which might be a crucial controller of $\mathrm{p}$-Akt expression in lovastatin-treated breast cancer cells. This reduction in DJ1 caused the reduction in the expression of $\mathrm{p}$-Akt in breast cancer cells and this influence was detected in the downstream of DJ-1/PTEN-regulated Akt pathway also on another important protein NDRG1 which plays a significant role in metastatic tumor progression (Bandyopadhyay et al., 2004; Klawitter et al., 2010). In xenograft tumor study by implanting MDA-MB-231 human breast cancer cell in mice, simvastatin treatment significantly showed the reduced p-Akt and increased PTEN level. This study also showed that simvastatin inhibited the phosphorylation of Akt indirectly also by inhibiting binding of NFKB transcription factor to DNA in the PTEN promoter region and allow the expression of PTEN to inhibit p-Akt (Ghosh-Choudhury et al., 2010). Fenofibrate, a non-statin cholesterol lowering drug is used in the therapy of hyperlipidemia and hypercholesterolemia. It is reported to act on $A k t / N F-\kappa B$ pathway and reduce the phosphorylated Akt and NF- $\mathrm{B}$ p65 in SKBR3 and MDA-MB231 cells (Sun et al., 2019). Akt/NF- $\kappa B$ pathway in breast cancer blocks the activity of pro-apoptotic genes such as Bok, Bax and BIM (Bentires-Alj et al., 2001; Inta et al., 2006). The effect of statins and fenofibrate on Akt shows that it is an important kinase molecule which on modulation can reduce the breast cancer tumorigenesis.

\section{Colorectal Cancer}

Colorectal cancer is the third most common cancer worldwide and the second most common cause of mortality in cancer (Globocan, 2020). The importance of Akt signaling has also been identified in suppressing colorectal cancer by cholesterollowering drugs. Mantha et al. (2005) showed the enhanced antiphosphorylation effects on Akt in colon cancer cell lines by combining lovastatin with gefitinib treatment. Xiao et al. (2008) found the synergistic effects of atorvastatin and celecoxib to inhibit the Akt activation in HCT116 and HT29 cells. It showed that celecoxib alone was required in a high concentration for modulating Akt, but the combination with atorvastatin reduced the required dose of celecoxib and increased the efficacy to inhibit p-Akt. This inhibition of Akt activation led to the modulation of crucial components of the Akt pathway such as PDK1, PI3K, and PTEN and showed anti-cancerous effects (Xiao et al., 2008). It is well known now that statins inhibit the phosphorylation of Akt in cancer cells and show anti-tumorigenic effects (Roudier et al., 2006; Klawitter et al., 2010; Huang et al., 2015). However, simvastatin in HCT116 and HT-29 colon cancer cells has shown elevated levels of p-Akt. This study showed that simvastatin activated Nrf2 (nuclear factor-erythroid 2-related factor 2), which on translocation to the nucleus induced the expression of HO-1 (heme oxygenase-1) related antioxidants via ERK and PI3K/Akt pathway (Jang et al., 2016). Nrf2 is a transcription factor activated in response to cellular stress. It activates the expression of antioxidant defense genes such as HO-1 and glutathione regulatory enzymes in response to ROS (Nguyen et al., 2003; Cuadrado and Rojo, 2008). Statins show their antioxidant and anti-inflammatory effect by inducing the expression of $\mathrm{HO}-1$ and reducing the free radicals formation (Lee et al., 2004; Jang et al., 2016). Although, this study of Jang et al. (2016) could not clear whether the activation of HO-1 by simvastatin protected the cancer cells or reduced the cell proliferation in colon cancer cells. Being the second deadliest cancer worldwide, the role of other cholesterol-lowering drugs on Akt signaling in colorectal cancer is required to explore and understand for better understanding of the mechanism of cholesterol-lowering drugs in the prevention of colorectal cancer.

\section{Prostate Cancer}

It is one of the most common cancer in men worldwide and a prominent cause of death in western countries. Statins have been associated with decreased metastasis and all-cause mortality among prostate cancer ( $\mathrm{PCa}$ ) patients (Lee E.J. et al., 2014; Raval et al., 2016). Akt is an important target molecule in the pathogenesis of PCa (Chen H. et al., 2016). Statins alone, as well as in combination with other drugs, can act on Akt and can inhibit its activation in PCa cells (Rogers et al., 2015; Wang et al., 2017; Sekine et al., 2018). Inhibition of Akt phosphorylation can promote PCa apoptosis and inhibit cell proliferation (Deng et al., 2019). FOXO is a transcription factor regulated by Akt through phosphorylation. It leads to the translocation of FOXO from the nucleus to the cytoplasm and modulates cell survival, growth, and apoptosis (Burgering and Kops, 2002; Lam et al., 2006). Akt/FOXO pathway can regulate cell growth, apoptosis, and survival (Song et al., 2005). Statins such as simvastatin and fluvastatin are reported to significantly reduce the phosphorylation of Akt and FOXO1 (a member of the FOXO family) and promote apoptosis in the PCa cells (Deng et al., 2019). In vitro studies in PCa cells show that simvastatin can reduce serum-induced cell migration, colony formation, invasion, and proliferation in prostate cancer. Not only this, it showed the reduced tumor growth in the xenograft model associated with reduced Akt activity (Kochuparambil et al., 2011). A part of PCa cells develops the steroidogenic ability to make androgens from the cholesterol, leading to castrationresistant (CR) prostate cancer. Novel statin derivatives are found to suppress the CR PCa tumorigenicity by inhibiting Akt and androgen receptor pathway. The inhibition of Akt by statins also inhibits the cell migratory ability of $\mathrm{PCa}$, which further supports their ability to inhibit tumorigenicity (Ingersoll et al., 2016). PCa cells contain cholesterol-rich lipid rafts that mediate the constitutive signaling through Akt via the mediation of epidermal growth factor (Zhuang et al., 2002). Statins lead to reduced cholesterol levels and disrupt these lipid rafts, leading to reduced cell survival (Chen X. et al., 2016). These studies indicate that the Akt pathway is one of the crucial targets for statins to mediate tumor suppression in PCa. These studies are further required to extend to other cholesterol-lowering drugs for the future course of PCa treatment. 


\section{Liver Cancer}

Liver cancer is the sixth most common cancer worldwide and the third common reason for cancer mortality (Globocan, 2020). A relation between statin treatment, reduction in Akt phosphorylation, and lung cancer reduction have also been established. In HepG2 cells, atorvastatin has been found to inhibit Akt phosphorylation and translocation to the nucleus in mTOR dependent manner. This inhibition of $\mathrm{p}$-Akt prevents the phosphorylation of GSK3 $\beta$ and cell proliferation (Roudier et al., 2006). Statin treatment causes the phosphorylation of mTOR and activates it, which inhibits insulin-induced Akt activation (Pääjärvi et al., 2005; Roudier et al., 2006; Tzatsos and Kandror, 2006). Huang et al. (2015) reported that simvastatin induced cytotoxic effects on HepG2 and Huh7 liver cancer cell lines. They observed that the level of p-Akt was reduced by simvastatin treatment in hepatocellular carcinoma (HCC) cells which were found to be associated with the Notch1 gene (Huang et al., 2015). Notch1 is a member of the Notch family whose role is to regulate growth, apoptosis, migration, and invasion of tumor cells (Ramdass et al., 2007; Wang et al., 2011; Lai et al., 2018). Following the knockout of the Notch1 gene, the simvastatin effect on p-Akt expression was diminished, and the apoptosis of HCC cells was attenuated (Huang et al., 2015). Statins, along with other drugs such as dasatinib (an anticancer drug), NS398 (COX-2 inhibitor), and celecoxib (COX-2 inhibitor), has shown synergistic effects on the inhibition of p-Akt in HCC cells (Gao et al., 2010; Lee S.J. et al., 2014; El Sayed et al., 2018). Other than statins, fenofibrate has shown anti-proliferative effects in Huh7 HCC cells by suppressing the phosphorylation of Akt (Yamasaki et al., 2011). Since p-Akt inhibits localization of p27 in the nucleus (Viglietto et al., 2002), fenofibrate led to the accumulation of p27 in the nucleus by inhibiting phosphorylation of Akt, which led to the cell cycle arrest. Interestingly, the suppression of growth of Huh7 HCC cells was found to be PPAR $\alpha$ independent (Yamasaki et al., 2011). Seeing the impact of cholesterol-lowering drugs on the Akt pathway, using them can be an effective strategy to treat/control hepatocellular carcinoma. There is a need to explore the effect of other cholesterol-lowering drugs on Akt and its targets for widening the understanding and new treatment strategies of HCC.

\section{Pancreatic Cancer}

Pancreatic cancer is the twelfth most common cancer worldwide and one of the deadliest human malignancies (WCRF, 2018; Globocan, 2020). Among pancreatic cancer incidences, 96\% are exocrine cancer, and pancreatic ductal adenocarcinoma (PDAC) is the predominant one (PCUK, 2018). Pancreatic cancer has a poor prognosis with an overall 5-year survival rate in $5 \%$ of affected people (Pourshams et al., 2019). The commonly affected pathways in pancreatic cancer are PI3K/Akt, NF-kB, and MAPK pathways (Altomare et al., 2002; Zhao et al., 2006; Holcomb et al., 2008). Akt pathway is reported to be overexpressed in pancreatic cancer cells and generate resistance against cytotoxic drugs such as gemcitabine (Ng et al., 2000). Thus, this pathway has attracted attention as an effective target to treat pancreatic cancer. Statins have shown the inhibition of pancreatic cancer cells in vivo as well as in vitro. Atorvastatin is one of the statins reported to decrease p-Akt in Panc-land MIA PaCa-2 cells and sensitized them toward cytotoxic drugs gemcitabine and 5Fu. It showed the ability to inhibit the constitutive expression of Akt as well as the insulin-induced expression of Akt in pancreatic cancer cells and thus affected Akt downstream targets. This treatment led to the prevention of cell proliferation and stimulation of cell apoptosis in pancreatic cancer cells (Mistafa and Stenius, 2009). Pancreatic intraepithelial neoplasia (PanIN) is the precursor of PDAC. The progression of PanIN from lowgrade PanIN (termed as PanIN-1) to high-grade PanIN (PanIN2 and -3 ) and then to ductal adenocarcinoma is believed to be the stages of progression to PDAC (Hruban et al., 2006). $\mathrm{PI} 3 /$ Akt pathway is associated with the expression of several

TABLE 1 | Clinical studies and their outcomes in cancer treatment by using cholesterol-lowering drugs.

\begin{tabular}{|c|c|c|c|c|c|c|}
\hline Type of cancer & $\begin{array}{l}\text { Cholesterol- } \\
\text { lowering } \\
\text { drug }\end{array}$ & $\begin{array}{l}\text { Clinical trial } \\
\text { phase }\end{array}$ & $\begin{array}{l}\text { Clinical trial } \\
\text { number }\end{array}$ & Status & Outcome & Reference \\
\hline Lung cancer & Simvastatin & Phase II & NCT00452244 & Completed & $\begin{array}{l}\text { Improved efficacy } \\
\text { of gefitinib }\end{array}$ & Han et al., 2011 \\
\hline \multirow[t]{2}{*}{ Breast cancer } & Atorvastatin & Phase ॥ & NCT00816244 & Completed & Anti-proliferative & Feldt et al., 2015 \\
\hline & Simvastatin & Phase II & NCT00334542 & Completed & $\begin{array}{c}\text { Decreased Estrone } \\
\text { sulphate }\end{array}$ & Higgins et al., 2012 \\
\hline \multirow[t]{2}{*}{ Colorectal cancer } & Simvastatin & Phase II & NCT02026583 & Completed & $\begin{array}{c}\text { Shows comparable } \\
\text { clinical efficacy } \\
\text { along with XELOX } \\
\text { and bevacizumab }\end{array}$ & Kim et al., 2019 \\
\hline & & Phase II & & Completed & $\begin{array}{l}\text { Increased time to } \\
\text { progression }\end{array}$ & Lee et al., 2009 \\
\hline Prostate cancer & Atorvastatin & - & - & - & $\begin{array}{l}\text { Reduced PSA } \\
\text { levels }\end{array}$ & $\begin{array}{l}\text { Khosropanah et al., } \\
2011\end{array}$ \\
\hline Pancreatic cancer & $\begin{array}{l}\text { Combination of } \\
\text { Evolocumab, } \\
\text { Atorvastatin, } \\
\text { Ezetimibe }\end{array}$ & Early phase I & NCT04862260 & Not yet recruiting & Not yet & $\begin{array}{c}\text { Chu de } \\
\text { Quebec-Universite } \\
\text { Laval, } 2021\end{array}$ \\
\hline
\end{tabular}


biomarkers involved in the passage from PanIN to PDAC. Atorvastatin inhibits this progression and becomes possible by regulating the PI3/Akt pathway (Mohammed et al., 2012). Akt also impacts the production of acetyl-CoA (Lee J.V.et al., 2014). ACLY is the enzyme involved in generating nucleo-cytosolic acetyl-CoA and is regulated by Akt at the upstream position (Lee J.V.et al., 2014; Carrer and Wellen, 2015). The production and availability of acetyl-CoA highly affect histone acetylation, a dynamic chromatin modification procedure involved in gene regulation (Wellen et al., 2009; Cardwell et al., 2015; Shi and $\mathrm{Tu}, 2015)$. In human PDAC, an association has been found between high histone acetylation levels and poor prognosis (Juliano et al., 2016). This Akt-ACLY signaling has been reported to be inhibited by treatment of statins and BET inhibitors which showed suppression of PDAC cell proliferation and tumor growth (Carrer et al., 2019). Overall in pancreatic cancer, statins are effective in impeding cell proliferation and tumor growth by targeting Akt.

\section{Other Cancers}

Oral cancer ranks at the sixteenth position for its incidences as well as mortality in overall cancer worldwide. The study on the effect of cholesterol-lowering drugs on Akt signaling in oral cancer has been minimal and needs to be extended further. One of these studies is by Jan et al. (2016) where fenofibrate was found to reduce Akt and p-Akt levels. Akt can directly communicate with mTOR and activate it, which is mediated by TSC2 and PRAS40 (Gwinn et al., 2008). Thus

TABLE 2 | Anti-tumorigenic effects of cholesterol-lowering drugs by targeting Akt and associated molecules.

\begin{tabular}{|c|c|c|c|c|c|}
\hline S.N. & Cancer type & $\begin{array}{l}\text { Cholesterol-lowering } \\
\text { drug }\end{array}$ & Molecule/pathway target & Effect on cancer cells & Reference \\
\hline \multirow[t]{5}{*}{ (1) } & Lung cancer & Simvastatin & Akt; Survivin; PARP & $\uparrow$ Apoptosis & Hwang et al., 2011 \\
\hline & & & Akt & $\uparrow$ Apoptosis & Kim et al., 2015 \\
\hline & & Lovastatin & Pl3k/Akt; ACLY & $\uparrow$ Anti-tumor & Hanai et al., 2012 \\
\hline & & & EGFR-PI3k-Akt; AMPK & $\uparrow A p o p t o s i s ~ \uparrow$ Radiation sensitization & Sanli et al., 2011 \\
\hline & & Fluvastatin & Akt; Braf/MEK/ERK1/2 & $\downarrow$ Growth $\uparrow$ Apoptosis & Zhang et al., 2019 \\
\hline \multirow[t]{7}{*}{ (2) } & Breast cancer & Atorvastatin & $\mathrm{p}-\mathrm{Akt}$ & $\downarrow$ Growth & Beckwitt et al., 2018 \\
\hline & & & PTEN/Akt; RhoB & $\downarrow$ Proliferation, $\downarrow$ Migration, $\uparrow$ Apoptosis & Ma et al., 2019 \\
\hline & & Simvastatin & PI3K/Akt/mTOR & $\uparrow$ Apoptosis, $\downarrow$ Proliferation & Wang et al., 2016 \\
\hline & & & PTEN/Akt & $\downarrow$ Cell viability & Park et al., 2013 \\
\hline & & & PTEN/Akt; NFкB & $\downarrow$ Growth & Ghosh-Choudhury et al., 2010 \\
\hline & & Lovastatin & PTEN/Akt; DJ-1; NDRG1 & $\downarrow$ Cell viability $\downarrow$ Metastasis & Klawitter et al., 2010 \\
\hline & & Fenofibrate & Akt/NF-кB & $\uparrow$ Apoptosis & Sun et al., 2019 \\
\hline \multirow[t]{2}{*}{ (3) } & Colorectal cancer & Lovastatin & Akt & $\uparrow$ Cytotoxicity & Mantha et al., 2005 \\
\hline & & Atorvastatin & Akt; PTEN; PI3k; PDK1 & $\uparrow$ Apoptosis $\downarrow$ Proliferation & Xiao et al., 2008 \\
\hline \multirow[t]{2}{*}{ (4) } & Prostate cancer & Simvastatin; fluvastatin & Akt/FOXO & $\uparrow$ Apoptosis & Deng et al., 2019 \\
\hline & & Atorvastatin & Akt; cholesterol synthesis & $\downarrow$ Cell survival & Chen X. et al., 2016 \\
\hline \multirow[t]{3}{*}{ (5) } & Liver cancer & Atorvastatin & Akt; mTOR; GSK3 $\beta$ & $\downarrow$ Proliferation & Roudier et al., 2006 \\
\hline & & Simvastatin & Akt; & $\uparrow$ Apoptosis & Huang et al., 2015 \\
\hline & & Fenofibrate & Akt & $\downarrow$ Proliferation & Yamasaki et al., 2011 \\
\hline \multirow[t]{3}{*}{ (6) } & Pancreatic cancer & Atorvastatin & Akt and its downstream targets & $\downarrow$ Proliferation $\uparrow$ Apoptosis & Mistafa and Stenius, 2009 \\
\hline & & & PI3/Akt & $\downarrow$ Progression & Mohammed et al., 2012 \\
\hline & & & Akt-ACLY & $\downarrow$ Proliferation $\downarrow$ Growth & Carrer et al., 2019 \\
\hline \multirow[t]{2}{*}{ (7) } & Oral cancer & Lovastatin & EGFR; PI3k/Akt & $\downarrow$ Proliferation $\downarrow$ Cell survival & Zhao et al., 2010 \\
\hline & & Fenofibrate & Akt/mTOR & $\downarrow$ Progression & Jan et al., 2016 \\
\hline \multirow[t]{4}{*}{ (8) } & Leukemia & $\begin{array}{l}\text { Statins (atorvastatin, } \\
\text { lovastatin, and simvastatin) }\end{array}$ & Akt/mTOR/p70S6K & $\uparrow$ Autophagy & Vilimanovich et al., 2015 \\
\hline & & Fluvastatin and simvastatin & Akt & $\downarrow$ Proliferation $\uparrow$ Apoptosis & Wang J.J. et al., 2018 \\
\hline & & Simvastatin & Akt & $\downarrow$ Proliferation $\uparrow$ Apoptosis & Zeng et al., 2012 \\
\hline & & Lovastatin & Ras/PI3K/Akt; Ras/Raf/ERK & $\downarrow$ Proliferation $\uparrow$ Apoptosis & Chen et al., 2015 \\
\hline (9) & Gliomas & Simvastatin & PI3K/Akt/caspase-3 & $\downarrow$ Proliferative $\downarrow$ Migration $\uparrow$ Apoptosis & Wu et al., 2009 \\
\hline
\end{tabular}




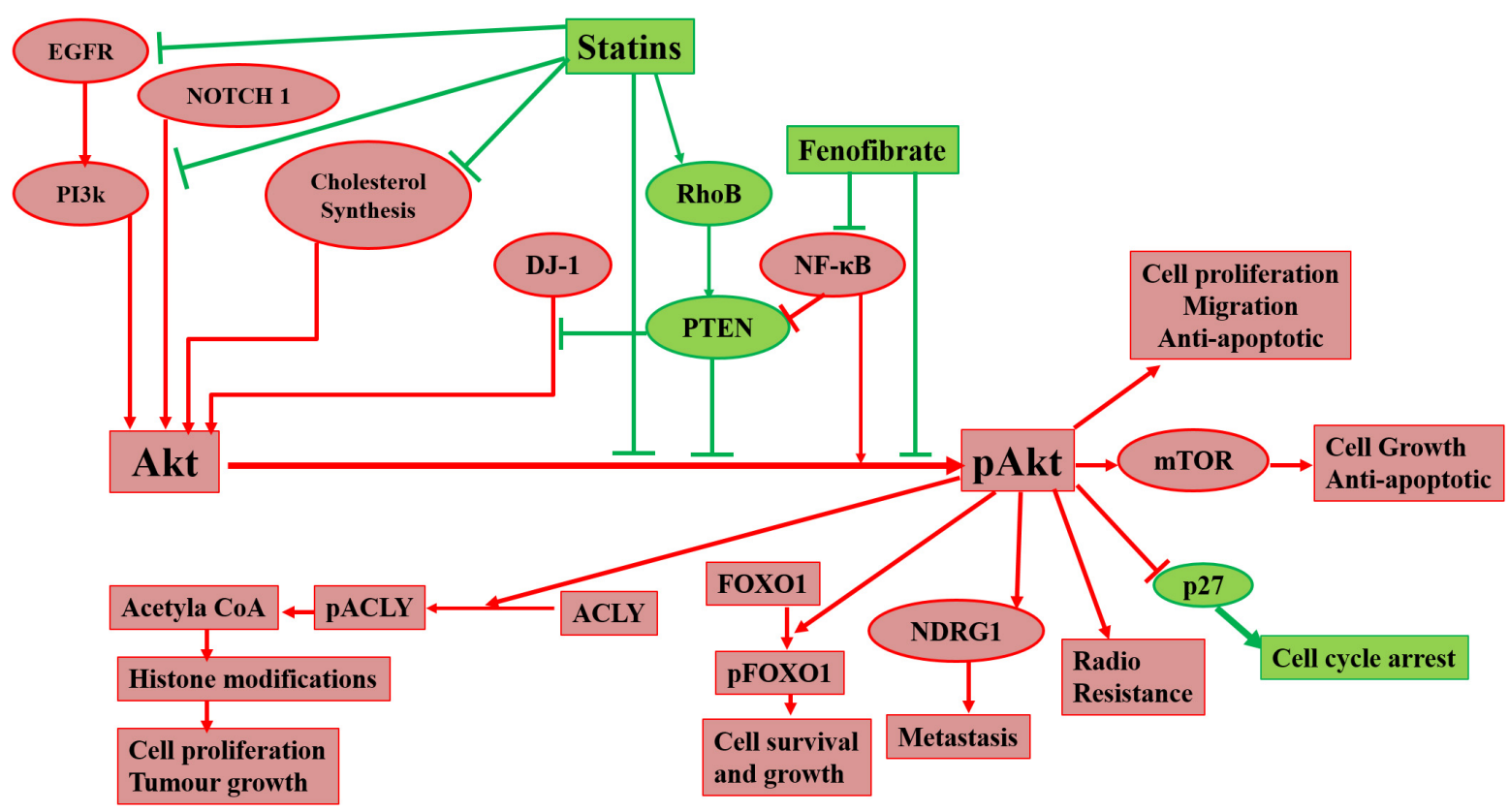

FIGURE 1 | Diagrammatic representation of effects of cholesterol-lowering drugs on Akt in cancer signaling. Statins can act on Akt via inhibition of cholesterol synthesis, EGFR, NOTCH 1, and the promotion of RhoB. Fenofibrate can also act on Akt via inhibition of NF-kB. Inhibition of Akt phosphorylation leads to prevention of radioresistance, cell proliferation, migration, and metastasis of cancer cells and promotion of apoptosis and cell cycle arrest.

inhibition of Akt by fenofibrate was associated with elevated expression of TSC2, which antagonized Rheb and reduced mTOR expression. This study did not find any role of PRAS40 and p-PRAS40 in mTOR inhibition by fenofibrate (Jan et al., 2016). Squamous cell carcinoma (SCC) is an epithelial malignancy. It has a limited treatment once converted into a metastatic disease (Greenlee et al., 2000; Breathnach et al., 2001). Receptor tyrosine kinase, mainly EGFR, is associated with the pathogenesis of SCC (Nicholson et al., 2001). Activation of EGFR triggers downstream signaling cascades, such as activation of the PI3K/Akt pathway that regulate cell proliferation and cell survival (Mendelsohn and Baselga, 2000; Dann and Thomas, 2006). Zhao et al. (2010) found that lovastatin can inhibit EGFR, resulting in the inhibition of Akt and its downstream targets in SCC. Statins have also shown anti-leukemic properties, as shown by Vilimanovich et al. (2015) in their studies. High cholesterol levels and metabolism are reported to be important factors for the survival of leukemic cells. Cholesterol synthesis and its import are highly active in these cells (Vitols et al., 1984; Rudling et al., 1998). Statins treatment leads to the reduction in the total cholesterol content of lipid rafts required for maintaining the activity of lipid raft residing Akt (Lasserre et al., 2008). It causes the reduced activation of Akt and its downstream targets mTOR and ribosomal p70S6 kinase in leukemic cells, which otherwise represses the autophagy. Thus, statins can be considered an inducer of autophagy in leukemic cells by inhibiting Akt/mTOR/p70S6K signaling (Vilimanovich et al., 2015). Human acute T lymphocytic leukemia (T-ALL) cells are significantly hampered by fluvastatin and simvastatin. They suppress the T-ALL cell proliferation and promote cell apoptosis by inhibiting the Akt pathway (Wang J.J. et al., 2018).
Zeng et al. (2012) showed the effects of simvastatin on human acute monocytic leukemia cell line SHI-1. They showed that simvastatin treatment inhibited cell proliferation and induced apoptosis in SHI-1 cells, which was found to be associated with the changes in the gene expression level of the Akt signaling pathway (Zeng et al., 2012). Cancer cells use glycolysis to generate ATP for fulfilling their energy requirement. Over activated glycolysis pathway generate Methylglyoxal (MG) as a byproduct from glyceraldehyde 3-phosphate and dihydroxyacetone phosphate in cancer cells (Phillips and Thornalley, 1993; Richard, 1993). MG is a cytotoxic product that prevents cell proliferation and promotes apoptosis in human leukemia HL-60 cells because of accumulation of MG-DNA adduct accumulation (Kang et al., 1996). Glyoxalase 1 (GLO1) detoxifies MG into D-lactate and protects the cells from damage caused by MG (Santarius et al., 2010). GLO1 is highly expressed in cancer cells (Hooper et al., 1987; Baunacke et al., 2014; Hu et al., 2014). Lovastatin is reported to suppress the expression of GLO1 and HMG-CoA by interrupting the translocation of NF- $\kappa$ B to the nucleus through inhibition of Ras/PI3K/Akt and Ras/Raf/ERK pathway in HL60 cells (Chen et al., 2015). Cholesterol-lowering drugs have also shown promising effects to inhibit brain tumors via Akt signaling. Gliomas are malignant primary brain tumors resistant to conventional therapies such as radiation and chemotherapy (Wu et al., 2009). Gliomas and other malignant brain tumors also show a high rate of cholesterol synthesis and increased HMG-CoA activity (Grieb et al., 1999). Simvastatin shows antiproliferative and anti-migration activity and induce apoptosis in U251 and U87 cells in a dose- and time-dependent manner. The modulation of PI3K/Akt/caspase-3 pathway in these cells where 
p-Akt level was reduced and caspase-3 level was increased led to the induction of apoptosis and showed anti-tumorigenic activity. The reduction in cholesterol content, modification of lipid rafts and translocation of Fas into the lipid rafts was also reported to inhibit U251 and U87 cells (Wu et al., 2009).

\section{CLINICAL RELEVANCE OF CHOLESTEROL-LOWERING DRUGS IN CANCER}

The use of cholesterol-lowering drugs in cancer prevention is well known now. This review article has discussed the significance of cholesterol-lowering drugs in cancer prevention via Akt modulation. Various clinical studies concerning the effects of cholesterol-lowering drugs in cancer treatment are undergoing and need to be completed. There are completed clinical studies also showing how cholesterol-lowering drugs may add a therapeutic approach to cancer treatment. Table $\mathbf{1}$ shows some of the clinical studies by using different cholesterollowering drugs on various types of cancers.

\section{CONCLUSION}

Raised cholesterol level is a concern for millions of people as it can lead to a high risk of heart disease. As per WHO, one-third of ischemic heart disease is associated with increased cholesterol levels (World Health Organisation, 2021). Other than heart disease, an increase in cholesterol levels raises the risk of tumorigenesis and elevated cholesterol is one of the characteristics of cancer cells. Cholesterol-lowering drugs have shown promising effects to treat/inhibit a wide range of cancers (Table 2) and our laboratory has also reported the same in previous studies (Ghosh-Choudhury et al., 2010; Mandal et al., 2011; Chowdhury et al., 2017). Among several cholesterol lowering drugs, statins are commonly used to control cholesterol levels and have been extensively studied to check anti-tumorigenic effects. Cholesterol-lowering drugs affect different signaling pathways in cancer cells (Figure 1). We had earlier noticed that anti-diabetic drug metformin and

\section{REFERENCES}

Alberts, A. W. (1988). Discovery, biochemistry and biology of lovastatin. Am. J. Cardiol. 62, 10J-15J. doi: 10.1016/0002-9149(88)90002-1

Altmann, S. W., Davis, H. R., Zhu, L.-J., Yao, X., Hoos, L. M., Tetzloff, G., et al. (2004). Niemann-Pick C1 Like 1 protein is critical for intestinal cholesterol absorption. Science 303, 1201-1204. doi: 10.1126/science.1093131

Altomare, D. A., Tanno, S., De Rienzo, A., Klein-Szanto, A. J., Tanno, S., Skele, K. L., et al. (2002). Frequent activation of AKT2 kinase in human pancreatic carcinomas. J. Cell. Biochem. 87, 470-476. doi: 10.1002/jcb.10287

Askham, J. M., Platt, F., Chambers, P. A., Snowden, H., Taylor, C. F., and Knowles, M. A. (2010). AKT1 mutations in bladder cancer: identification of a novel oncogenic mutation that can co-operate with E17K. Oncogene 29, 150-155. doi: 10.1038 /onc. 2009.315

Aylon, Y., and Oren, M. (2016). The Hippo pathway, p53 and cholesterol. Cell Cycle 15, 2248-2255. doi: 10.1080/15384101.2016.1207840
$N$-arachidonoyl dopamine inhibit breast cancer growth and epithelial to mesenchymal transition by decreasing cholesterol content in cancer cells (Sharma et al., 2019; Bandyopadhayaya et al., 2021). Akt is one of the most common signaling pathways in cancer cells for cell survival, angiogenesis, and tumorigenesis. It increases glucose metabolism and promotes lipogenesis. It promotes the SREBP, one of the critical regulators for cholesterol synthesis and a target of statins. The effect of cholesterol-lowering drugs via Akt signaling has been reported in several cancer types, but need to be further extended. These drugs can modulate several Akt pathways and show the anti-tumorigenic effects. These drugs can inhibit survivin to induce apoptosis and can radio sensitize the cancer cells by inhibiting Akt signaling. They overcome the resistance of cancer cells against the cytotoxic drugs via Akt inhibition. All these aspects manifest the importance of Akt as a key target of cholesterol-lowering drugs to inhibit tumorigenesis. Indeed, activation of NF-kB which is a key downstream target of Akt is also responsible for the development of chemoresistance. Our study revealed that cholesterol lowering simvastatin inhibits NF-kB by targeting PTEN/Akt signaling to attenuate cancer growth (Ghosh-Choudhury et al., 2010). Our other studies documented that omega-3 fatty acids target $\mathrm{PI} 3 \mathrm{~K} / \mathrm{Akt} / \mathrm{NF}-\mathrm{kB}$ axis, and inhibit cancer growth and metastasis in breast cancer models (Ghosh-Choudhury et al., 2009; Mandal et al., 2010, 2012). Thus, the combination of statins and omega-3 fatty acids might work effectively in controlling cancer growth in chemoresistance cells. Despite these studies, there is a requirement to study the effect of inhibition of Akt signaling by different categories of cholesterol-lowering drugs on tumorigenesis as these studies are still limitedly done. Not only this, these studies are further required to expand to other cancers so that an overall picture of the effects of these drugs on Akt signaling could be drawn.

\section{AUTHOR CONTRIBUTIONS}

NK collected information, prepared the tables and figures, drafted and wrote the manuscript. CCM formulated the study and written the manuscript. Both authors contributed to the article and approved the submitted version.

Bandyopadhayaya, S., Akimov, M. G., Verma, R., Sharma, A., Sharma, D., Kundu, G. C., et al. (2021). N-arachidonoyl dopamine inhibits epithelial-mesenchymal transition of breast cancer cells through ERK signaling and decreasing the cellular cholesterol. J. Biochem. Mol. Toxicol. 35:e22693. doi: 10.1002/jbt.2 2693

Bandyopadhyay, S., Pai, S. K., Hirota, S., Hosobe, S., Tsukada, T., Miura, K., et al. (2004). PTEN up-regulates the tumor metastasis suppressor gene Drg-1 in prostate and breast cancer. Cancer Res. 64, 7655-7660. doi: 10.1158/0008-5472. CAN-04-1623

Baunacke, M., Horn, L.-C., Trettner, S., Engel, K. M. Y., Hemdan, N. Y. A., Wiechmann, V., et al. (2014). Exploring glyoxalase 1 expression in prostate cancer tissues: targeting the enzyme by ethyl pyruvate defangs some malignancy-associated properties. Prostate 74, 48-60. doi: 10.1002/pros.22728

Beckwitt, C. H., Shiraha, K., and Wells, A. (2018). Lipophilic statins limit cancer cell growth and survival, via involvement of Akt signaling. PloS One 13:e197422. doi: 10.1371/journal.pone.0197422 
Bellacosa, A., de Feo, D., Godwin, A. K., Bell, D. W., Cheng, J. Q., Altomare, D. A., et al. (1995). Molecular alterations of the AKT2 oncogene in ovarian and breast carcinomas. Int. J. Cancer 64, 280-285. doi: 10.1002/ijc.2910640412

Bellacosa, A., Franke, T. F., Gonzalez-Portal, M. E., Datta, K., Taguchi, T., Gardner, J., et al. (1993). Structure, expression and chromosomal mapping of c-akt: relationship to v-akt and its implications. Oncogene 8, 745-754.

Bentires-Alj, M., Dejardin, E., Viatour, P., Van Lint, C., Froesch, B., Reed, J. C., et al. (2001). Inhibition of the NF-kappa B transcription factor increases Bax expression in cancer cell lines. Oncogene 20, 2805-2813. doi: 10.1038/sj.onc. 1204343

Berwick, D. C., Hers, I., Heesom, K. J., Moule, S. K., and Tavare, J. M. (2002). The identification of ATP-citrate lyase as a protein kinase B (Akt) substrate in primary adipocytes. J. Biol. Chem. 277, 33895-33900. doi: 10.1074/jbc. M204681200

Breathnach, O. S., Freidlin, B., Conley, B., Green, M. R., Johnson, D. H., Gandara, D. R., et al. (2001). Twenty-two years of phase III trials for patients with advanced Non-small-cell lung cancer: sobering results. J. Clin. Oncol. 19, 1734-1742. doi: 10.1200/JCO.2001.19.6.1734

Brewer, H. B., and Santamarina-Fojo, S. (2003). New insights into the role of the adenosine triphosphate-binding cassette transporters in high-density lipoprotein metabolism and reverse cholesterol transport. Am. J. Cardiol. 91, 3E-11E. doi: 10.1016/s0002-9149(02)03382-9

Bruckert, E., Giral, P., and Tellier, P. (2003). Perspectives in cholesterol-lowering therapy: the role of ezetimibe, a new selective inhibitor of intestinal cholesterol absorption. Circulation 107, 3124-3128. doi: 10.1161/01.CIR.0000072345. 98581.24

Burgering, B. M. T., and Kops, G. J. P. L. (2002). Cell cycle and death control: long live Forkheads. Trends Biochem. Sci. 27, 352-360. doi: 10.1016/s0968-0004(02) 02113-8

Cardwell, C. R., Hicks, B. M., Hughes, C., and Murray, L. J. (2015). Statin use after diagnosis of breast cancer and survival: a populationbased cohort study. Epidemiology 26, 68-78. doi: 10.1097/EDE.000000000 0000189

Carrer, A., Trefely, S., Zhao, S., Campbell, S. L., Norgard, R. J., Schulz, K. C., et al. (2019). Acetyl-CoA metabolism supports multi-step pancreatic tumorigenesis. Cancer Discov. 9, 416-435. doi: 10.1158/2159-8290.CD-18 $-0567$

Carrer, A., and Wellen, K. E. (2015). Metabolism and epigenetics: a link cancer cells exploit. Curr. Opin. Biotechnol. 34, 23-29. doi: 10.1016/j.copbio.2014.11.012

Catapano, A. L., Graham, I., De Backer, G., Wiklund, O., Chapman, M. J., Drexel, H., et al. (2016). 2016 ESC/EAS guidelines for the management of dyslipidaemias. Eur. Heart J. 37, 2999-3058. doi: 10.1093/eurheartj/ehw272

Cerami, E., Gao, J., Dogrusoz, U., Gross, B. E., Sumer, S. O., Aksoy, B. A., et al. (2012). The cBio cancer genomics portal: an open platform for exploring multidimensional cancer genomics data. Cancer Discov. 2, 401-404. doi: 10. 1158/2159-8290.CD-12-0095

Chan, C.-H., Jo, U., Kohrman, A., Rezaeian, A. H., Chou, P.-C., Logothetis, C., et al. (2014). Posttranslational regulation of Akt in human cancer. Cell Biosci. 4:59. doi: 10.1186/2045-3701-4-59

Chan, C.-H., Li, C.-F., Yang, W.-L., Gao, Y., Lee, S.-W., Feng, Z., et al. (2012). The Skp2-SCF E3 ligase regulates akt ubiquitination, glycolysis, herceptin sensitivity, and tumorigenesis. Cell 151, 913-914. doi: 10.1016/j.cell.2012.10. 025

Chan, L.-K., Ho, D. W.-H., Kam, C. S., Chiu, E. Y.-T., Lo, I. L.-O., Yau, D. T.W., et al. (2021). RSK2-inactivating mutations potentiate MAPK signaling and support cholesterol metabolism in hepatocellular carcinoma. J. Hepatol. 74, 360-371. doi: 10.1016/j.jhep.2020.08.036

Chen, C.-C., Liu, T.-Y., Huang, S.-P., Ho, C.-T., and Huang, T.-C. (2015). Differentiation and apoptosis induction by lovastatin and $\gamma$-tocotrienol in HL60 cells via Ras/ERK/NF- $\kappa \mathrm{B}$ and Ras/Akt/NF- $\kappa \mathrm{B}$ signaling dependent downregulation of glyoxalase 1 and HMG-CoA reductase. Cell. Signal. 27, 2182-2190. doi: 10.1016/j.cellsig.2015.07.014

Chen, H., Zhou, L., Wu, X., Li, R., Wen, J., Sha, J., et al. (2016). The PI3K/AKT pathway in the pathogenesis of prostate cancer. Front. Biosci. 21:1084-1091. doi: $10.2741 / 4443$

Chen, X., Liu, Y., Wu, J., Huang, H., Du, Z., Zhang, K., et al. (2016). Mechanistic study of inhibitory effects of atorvastatin and docetaxel in combination on prostate cancer. Cancer Genom. Proteom. 13, 151-160.
Chen, Z., Fillmore, C. M., Hammerman, P. S., Kim, C. F., and Wong, K.-K. (2014). Non-small-cell lung cancers: a heterogeneous set of diseases. Nat. Rev. Cancer 14, 535-546. doi: 10.1038/nrc3775

Cheng, J. Q., Ruggeri, B., Klein, W. M., Sonoda, G., Altomare, D. A., Watson, D. K., et al. (1996). Amplification of AKT2 in human pancreatic cells and inhibition of AKT2 expression and tumorigenicity by antisense RNA. Proc. Natl. Acad. Sci. U S A. 93, 3636-3641. doi: 10.1073/pnas.93.8.3636

Chowdhury, K., Sharma, A., Sharma, T., Kumar, S., and Mandal, C. C. (2017). Simvastatin and MBCD inhibit breast cancer-induced osteoclast activity by targeting osteoclastogenic factors. Cancer Invest. 35, 403-413. doi: 10.1080/ 07357907.2017.1309548

Christenson, L. K., and Strauss, J. F. (2000). Steroidogenic acute regulatory protein (StAR) and the intramitochondrial translocation of cholesterol. Biochim. Biophys. Acta 1529, 175-187. doi: 10.1016/s1388-1981(00)00147-5

Chu de Quebec-Universite Laval (2021). A Phase 1 Feasibility Study of Cholesterol Metabolism Disruption (Evolocumab, Atorvastatin and Ezetimibe) in Combination with FOLFIRINOX in Patients With Metastatic Pancreatic Adenocarcinoma. clinicaltrials.gov. Available online at: https://clinicaltrials.gov/ ct2/show/NCT04862260 (accessed May 27, 2021).

Cuadrado, A., and Rojo, A. I. (2008). Heme oxygenase-1 as a therapeutic target in neurodegenerative diseases and brain infections. Curr. Pharm. Design 14, 429-442. doi: 10.2174/138161208783597407

Dann, S. G., and Thomas, G. (2006). The amino acid sensitive TOR pathway from yeast to mammals. FEBS Lett. 580, 2821-2829. doi: 10.1016/j.febslet.2006.04. 068

Das, F., Ghosh-Choudhury, N., Dey, N., Mandal, C. C., Mahimainathan, L., Kasinath, B. S., et al. (2012). Unrestrained mammalian target of rapamycin complexes 1 and 2 increase expression of phosphatase and tensin homolog deleted on chromosome 10 to regulate phosphorylation of Akt kinase. J. Biol. Chem. 287, 3808-3822. doi: 10.1074/jbc.M111.246397

Datta, S. R., Brunet, A., and Greenberg, M. E. (1999). Cellular survival: a play in three Akts. Genes Dev. 13, 2905-2927. doi: 10.1101/gad.13.22.2905

Deng, J.-L., Zhang, R., Zeng, Y., Zhu, Y.-S., and Wang, G. (2019). Statins induce cell apoptosis through a modulation of AKT/FOXO1 pathway in prostate cancer cells. Cancer Manag. Res. 11, 7231-7242. doi: 10.2147/CMAR.S212643

Deprez, J., Vertommen, D., Alessi, D. R., Hue, L., and Rider, M. H. (1997). Phosphorylation and activation of heart 6-phosphofructo-2-kinase by protein kinase B and other protein kinases of the insulin signaling cascades. J. Biol. Chem. 272, 17269-17275. doi: 10.1074/jbc.272.28.17269

Di Bello, E., Zwergel, C., Mai, A., and Valente, S. (2020). The innovative potential of statins in cancer: new targets for new therapies. Front. Chem. 8:516. doi: 10.3389/fchem.2020.00516

Dimitroulakos, J., Lorimer, I. A., and Goss, G. (2006). Strategies to enhance epidermal growth factor inhibition: targeting the mevalonate pathway. Clin. Cancer Res. 12, 4426s-4431s. doi: 10.1158/1078-0432.CCR-06-0089

Dong, F., Mo, Z., Eid, W., Courtney, K. C., and Zha, X. (2014). Akt inhibition promotes ABCA1-mediated cholesterol efflux to ApoA-I through suppressing mTORC1. PloS One 9:e113789. doi: 10.1371/journal.pone.0113789

Downward, J. (2003). Targeting RAS signalling pathways in cancer therapy. Nat. Rev. Cancer 3, 11-22. doi: 10.1038/nrc969

El Sayed, I., Helmy, M. W., and El-Abhar, H. S. (2018). Inhibition of SRC/FAK cue: A novel pathway for the synergistic effect of rosuvastatin on the anticancer effect of dasatinib in hepatocellular carcinoma. Life Sci. 213, 248-257. doi: 10.1016/j.lfs.2018.10.002

Engelman, J. A. (2009). Targeting PI3K signalling in cancer: opportunities, challenges and limitations. Nat. Rev. Cancer 9, 550-562. doi: 10.1038/nrc 2664

Feingold, K. R. (2000). "Cholesterol Lowering Drugs," in Endotext, eds K. R. Feingold, B. Anawalt, A. Boyce, G. Chrousos, W. W. de Herder, K. Dungan, et al. (. (South Dartmouth, MA: MDText.com, Inc).

Feldt, M., Bjarnadottir, O., Kimbung, S., Jirström, K., Bendahl, P.-O., Veerla, S., et al. (2015). Statin-induced anti-proliferative effects via cyclin D1 and p27 in a window-of-opportunity breast cancer trial. J. Transl. Med. 13:133. doi: 10.1186/s12967-015-0486-0

Fornaro, M., Plescia, J., Chheang, S., Tallini, G., Zhu, Y.-M., King, M., et al. (2003). Fibronectin protects prostate cancer cells from tumor necrosis factoralpha-induced apoptosis via the AKT/survivin pathway. J. Biol. Chem. 278, 50402-50411. doi: 10.1074/jbc.M307627200 
Galbraith, L. C. A., Mui, E., Nixon, C., Hedley, A., Strachan, D., MacKay, G., et al. (2021). PPAR-gamma induced AKT3 expression increases levels of mitochondrial biogenesis driving prostate cancer. Oncogene 40, 2355-2366. doi: 10.1038/s41388-021-01707-7

Gao, J., Li, J.-S., Xu, G.-L., Jia, W.-D., Ma, J.-L., Yu, J.-H., et al. (2010). [Effects of celecoxib combined with fluvastatin on tumor growth and cell apoptosis in a xenograft model of hepatocellular carcinoma]. Zhonghua Gan Zang Bing Za Zhi 18, 900-904. doi: 10.3760/cma.j.issn.1007-3418.2010.12.005

Ghosh-Choudhury, N., Mandal, C. C., Das, F., Ganapathy, S., Ahuja, S., and Ghosh Choudhury, G. (2013). c-Abl-dependent molecular circuitry involving Smad5 and phosphatidylinositol 3-kinase regulates bone morphogenetic protein-2induced osteogenesis. J. Biol. Chem. 288, 24503-24517. doi: 10.1074/jbc.M113. 455733

Ghosh-Choudhury, N., Mandal, C. C., Ghosh-Choudhury, N., and Ghosh Choudhury, G. (2010). Simvastatin induces derepression of PTEN expression via NFkappaB to inhibit breast cancer cell growth. Cell. Signal. 22, 749-758. doi: 10.1016/j.cellsig.2009.12.010

Ghosh-Choudhury, T., Mandal, C. C., Woodruff, K., St Clair, P., Fernandes, G., Choudhury, G. G., et al. (2009). Fish oil targets PTEN to regulate NFkappaB for downregulation of anti-apoptotic genes in breast tumor growth. Breast Cancer Res. Treatment 118, 213-228. doi: 10.1007/s10549-008-0227-7

Giacomini, I., Gianfanti, F., Desbats, M. A., Orso, G., Berretta, M., Prayer-Galetti, T., et al. (2021). Cholesterol metabolic reprogramming in cancer and its pharmacological modulation as therapeutic strategy. Front. Oncol. 11:682911. doi: $10.3389 /$ fonc.2021.682911

Globocan. (2020). Cancer Fact Sheets. Lyon, France: Internationa Agency for Research on Cancer.

Goldstein, J. L., and Brown, M. S. (2009). The LDL receptor. Arterioscl. Thrombosis Vasc. Biol. 29, 431-438. doi: 10.1161/ATVBAHA.108.179564

Gottlob, K., Majewski, N., Kennedy, S., Kandel, E., Robey, R. B., and Hay, N. (2001). Inhibition of early apoptotic events by Akt/PKB is dependent on the first committed step of glycolysis and mitochondrial hexokinase. Genes Dev. 15, 1406-1418. doi: 10.1101/gad.889901

Greenlee, R. T., Murray, T., Bolden, S., and Wingo, P. A. (2000). Cancer statistics, 2000. CA Cancer J. Clin. 50, 7-33. doi: 10.3322/canjclin.50.1.7

Grieb, P., Ryba, M. S., Jagielski, J., Gackowski, W., Paczkowski, P., and Chrapusta, S. J. (1999). Serum cholesterol in cerebral malignancies. J. Neuro-Oncol. 41, 175-180. doi: 10.1023/a:1006131418126

Gupta, A., Stokes, W., Eguchi, M., Hararah, M., Amini, A., Mueller, A., et al. (2019). Statin use associated with improved overall and cancer specific survival in patients with head and neck cancer. Oral Oncol. 90, 54-66. doi: 10.1016/j. oraloncology.2019.01.019

Gupta, A. K., McKenna, W. G., Weber, C. N., Feldman, M. D., Goldsmith, J. D., Mick, R., et al. (2002). Local recurrence in head and neck cancer: relationship to radiation resistance and signal transduction. Clin. Cancer Res. 8, 885-892.

Gwinn, D. M., Shackelford, D. B., Egan, D. F., Mihaylova, M. M., Mery, A., Vasquez, D. S., et al. (2008). AMPK phosphorylation of raptor mediates a metabolic checkpoint. Mol. Cell. 30, 214-226. doi: 10.1016/j.molcel.2008.03.003

Han, F., Li, C.-F., Cai, Z., Zhang, X., Jin, G., Zhang, W.-N., et al. (2018). The critical role of AMPK in driving Akt activation under stress, tumorigenesis and drug resistance. Nat. Commun. 9:4728. doi: 10.1038/s41467-018-07 188-9

Han, J.-Y., Lee, S.-H., Yoo, N. J., Hyung, L. S., Moon, Y. J., Yun, T., et al. (2011). A randomized phase II study of gefitinib plus simvastatin versus gefitinib alone in previously treated patients with advanced non-small cell lung cancer. Clin. Cancer Res. 17, 1553-1560. doi: 10.1158/1078-0432.CCR-10-2525

Hanai, J.-I., Doro, N., Sasaki, A. T., Kobayashi, S., Cantley, L. C., Seth, P., et al. (2012). Inhibition of lung cancer growth: ATP citrate lyase knockdown and statin treatment leads to dual blockade of Mitogen-Activated Protein Kinase (MAPK) and Phosphatidylinositol-3-Kinase (PI3K)/AKT Pathways. J. Cell. Physiol. 227, 1709-1720. doi: 10.1002/jcp.22895

Hatzivassiliou, G., Zhao, F., Bauer, D. E., Andreadis, C., Shaw, A. N., Dhanak, D., et al. (2005). ATP citrate lyase inhibition can suppress tumor cell growth. Cancer Cell 8, 311-321. doi: 10.1016/j.ccr.2005.09.008

Higgins, M. J., Prowell, T. M., Blackford, A. L., Byrne, C., Khouri, N. F., Slater, S. A., et al. (2012). A short-term biomarker modulation study of simvastatin in women at increased risk of a new breast cancer. Breast Cancer Res. Treat. 131, 915-924. doi: 10.1007/s10549-011-1858-7
Holcomb, B., Yip-Schneider, M., and Schmidt, C. M. (2008). The role of nuclear factor kappaB in pancreatic cancer and the clinical applications of targeted therapy. Pancreas 36, 225-235. doi: 10.1097/MPA.0b013e31815b3207

Hooper, N. I., Tisdale, M. J., and Thornalley, P. J. (1987). Glyoxalase activity during differentiation of human leukaemia cells in vitro. Leukemia Res. 11, 1141-1148. doi: 10.1016/0145-2126(87)90169-x

Hruban, R. H., Adsay, N. V., Albores-Saavedra, J., Anver, M. R., Biankin, A. V., Boivin, G. P., et al. (2006). Pathology of genetically engineered mouse models of pancreatic exocrine cancer: consensus report and recommendations. Cancer Res. 66, 95-106. doi: 10.1158/0008-5472.CAN-05-2168

Hsu, L.-H., Chu, N.-M., and Kao, S.-H. (2017). Estrogen, estrogen receptor and lung cancer. Int. J. Mol. Sci. 18:1713. doi: 10.3390/ijms18081713

Hu, T., Shen, H., Huang, H., Yang, Z., Zhou, Y., and Zhao, G. (2020). Cholesterollowering drug pitavastatin targets lung cancer and angiogenesis via suppressing prenylation-dependent Ras/Raf/MEK and PI3K/Akt/mTOR signaling. AntiCancer Drugs 31, 377-384. doi: 10.1097/CAD.0000000000000885

$\mathrm{Hu}, \mathrm{X}$., Yang, X., He, Q., Chen, Q., and Yu, L. (2014). Glyoxalase 1 is up-regulated in hepatocellular carcinoma and is essential for HCC cell proliferation. Biotechnol. Lett. 36, 257-263. doi: 10.1007/s10529-013-1372-6

Huang, B., Song, B.-L., and Xu, C. (2020). Cholesterol metabolism in cancer: mechanisms and therapeutic opportunities. Nat. Metabol. 2, 132-141. doi: 10. 1038/s42255-020-0174-0

Huang, X., Ma, J., Xu, J., Su, Q., and Zhao, J. (2015). Simvastatin induces growth inhibition and apoptosis in HepG2 and Huh7 hepatocellular carcinoma cells via upregulation of Notch1 expression. Mol. Med. Rep. 11, 2334-2340. doi: 10.3892/mmr.2014.2976

Hwang, K.-E., Na, K.-S., Park, D.-S., Choi, K.-H., Kim, B.-R., Shim, H., et al. (2011). Apoptotic induction by simvastatin in human lung cancer A549 cells via Akt signaling dependent down-regulation of survivin. Invest. New Drugs 29, 945-952. doi: 10.1007/s10637-010-9450-2

Icard, P., Wu, Z., Fournel, L., Coquerel, A., Lincet, H., and Alifano, M. (2020). ATP citrate lyase: A central metabolic enzyme in cancer. Cancer Lett. 471, 125-134. doi: 10.1016/j.canlet.2019.12.010

Ikonen, E. (2008). Cellular cholesterol trafficking and compartmentalization. Nat. Rev. Mol. Cell Biol. 9, 125-138. doi: 10.1038/nrm2336

Ingersoll, M. A., Miller, D. R., Martinez, O., Wakefield, C. B., Hsieh, K.-C., Simha, M. V., et al. (2016). Statin derivatives as therapeutic agents for castrationresistant prostate cancer. Cancer Lett. 383, 94-105. doi: 10.1016/j.canlet.2016. 09.008

Inta, I., Paxian, S., Maegele, I., Zhang, W., Pizzi, M., Spano, P., et al. (2006). Bim and Noxa are candidates to mediate the deleterious effect of the NF-kappa B subunit RelA in cerebral ischemia. J. Neurosci. 26, 12896-12903. doi: 10.1523/ JNEUROSCI.3670-06.2006

Jan, C.-I., Tsai, M.-H., Chiu, C.-F., Huang, Y.-P., Liu, C. J., and Chang, N. W. (2016). Fenofibrate suppresses oral tumorigenesis via reprogramming metabolic processes: potential drug repurposing for oral cancer. Int. J. Biol. Sci. 12, 786-798. doi: 10.7150/ijbs.13851

Jang, H. J., Hong, E. M., Kim, M., Kim, J. H., Jang, J., Park, S. W., et al. (2016). Simvastatin induces heme oxygenase-1 via NF-E2-related factor 2 (Nrf2) activation through ERK and PI3K/Akt pathway in colon cancer. Oncotarget 7, 46219-46229. doi: 10.18632/oncotarget.10078

Jiang, K., Sun, J., Cheng, J., Djeu, J. Y., Wei, S., and Sebti, S. (2004). Akt mediates Ras downregulation of RhoB, a suppressor of transformation, invasion, and metastasis. Mol. Cell. Biol. 24, 5565-5576. doi: 10.1128/MCB.24.12.5565-5576. 2004

Jie, Z., Xie, Z., Xu, W., Zhao, X., Jin, G., Sun, X., et al. (2019). SREBP-2 aggravates breast cancer associated osteolysis by promoting osteoclastogenesis and breast cancer metastasis. Biochim. Biophys. Acta. Mol. Basis Dis. 1865, 115-125. doi: 10.1016/j.bbadis.2018.10.026

Joshi, P. H., and Jacobson, T. A. (2010). Therapeutic options to further lower C-reactive protein for patients on statin treatment. Curr. Atheroscl. Rep. 12, 34-42. doi: 10.1007/s11883-009-0075-X

Juliano, C. N., Izetti, P., Pereira, M. P., Dos Santos, A. P., Bravosi, C. P., Abujamra, A. L., et al. (2016). H4K12 and H3K18 acetylation associates with poor prognosis in pancreatic cancer. Appl. Immunohistochem. Mol. Morphol. 24, 337-344. doi: 10.1097/PAI.0000000000000194

Jun, S. Y., Brown, A. J., Chua, N. K., Yoon, J.-Y., Lee, J.-J., Yang, J. O., et al. (2020). Reduction of squalene epoxidase by cholesterol accumulation 
accelerates colorectal cancer progression and metastasis. Gastroenterology 160, 1194-1207. doi: 10.1053/j.gastro.2020.09.009

Kang, Y., Edwards, L. G., and Thornalley, P. J. (1996). Effect of methylglyoxal on human leukaemia 60 cell growth: modification of DNA G1 growth arrest and induction of apoptosis. Leukemia Res. 20, 397-405. doi: 10.1016/0145-2126(95) 00162-x

Khosropanah, I., Falahatkar, S., Farhat, B., Heidari Bateni, Z., Enshaei, A., Allahkhah, A. A., et al. (2011). Assessment of atorvastatin effectiveness on serum PSA level in hypercholesterolemic males. Acta Med. Iranica 49, 789-794.

Kim, K.-Y., Baek, A., Hwang, J.-E., Choi, Y. A., Jeong, J., Lee, M.-S., et al. (2009). Adiponectin-activated AMPK stimulates dephosphorylation of AKT through protein phosphatase 2A activation. Cancer Res. 69, 4018-4026. doi: 10.1158/ 0008-5472.CAN-08-2641

Kim, R. H., Peters, M., Jang, Y., Shi, W., Pintilie, M., Fletcher, G. C., et al. (2005). DJ-1, a novel regulator of the tumor suppressor PTEN. Cancer Cell 7, 263-273. doi: 10.1016/j.ccr.2005.02.010

Kim, Y., Kim, T. W., Han, S. W., Ahn, J. B., Kim, S. T., Lee, J., et al. (2019). A Single Arm, Phase II study of simvastatin plus XELOX and Bevacizumab as first-line chemotherapy in metastatic colorectal cancer patients. Cancer Res. Treatment 51, 1128-1134. doi: 10.4143/crt.2018.379

Kim, Y.-S., Seol, C.-H., Jung, J.-W., Oh, S.-J., Hwang, K.-E., Kim, H.-J., et al. (2015). Synergistic effect of sulindac and simvastatin on apoptosis in lung cancer A549 Cells through AKT-dependent downregulation of Survivin. Cancer Res. Treatment 47, 90-100. doi: 10.4143/crt.2013.194

Kitahara, C. M., Berrington de González, A., Freedman, N. D., Huxley, R., Mok, Y., Jee, S. H., et al. (2011). Total cholesterol and cancer risk in a large prospective study in Korea. J. Clin. Oncol. 29, 1592-1598. doi: 10.1200/JCO.2010.31.5200

Kizilboga, T., Baskale, E. A., Yildiz, J., Akcay, I. M., Zemheri, E., Can, N. D., et al. (2019). Bag-1 stimulates Bad phosphorylation through activation of Akt and Raf kinases to mediate cell survival in breast cancer. BMC Cancer 19:1254. doi: 10.1186/s12885-019-6477-4

Klawitter, J., Shokati, T., Moll, V., Christians, U., and Klawitter, J. (2010). Effects of lovastatin on breast cancer cells: a proteo-metabonomic study. Breast Cancer Res. 12:R16. doi: 10.1186/bcr2485

Knobbe, C. B., and Reifenberger, G. (2003). Genetic alterations and aberrant expression of genes related to the phosphatidyl-inositol-3'-kinase/protein kinase B (Akt) signal transduction pathway in glioblastomas. Brain Pathol. 13, 507-518. doi: 10.1111/j.1750-3639.2003.tb00481.x

Kochuparambil, S. T., Al-Husein, B., Goc, A., Soliman, S., and Somanath, P. R. (2011). Anticancer efficacy of simvastatin on prostate cancer cells and tumor xenografts is associated with inhibition of Akt and reduced prostate-specific antigen expression. J. Pharmacol. Exper. Therap. 336, 496-505. doi: 10.1124/ jpet. 110.174870

Kohn, A. D., Summers, S. A., Birnbaum, M. J., and Roth, R. A. (1996). Expression of a constitutively active Akt Ser/Thr kinase in 3T3-L1 adipocytes stimulates glucose uptake and glucose transporter 4 translocation. J. Biol. Chem. 271, 31372-31378. doi: 10.1074/jbc.271.49.31372

Koundouros, N., and Poulogiannis, G. (2018). Phosphoinositide 3-Kinase/Akt signaling and redox metabolism in cancer. Front. Oncol. 8:160. doi: 10.3389/ fonc. 2018.00160

Koundouros, N., and Poulogiannis, G. (2020). Reprogramming of fatty acid metabolism in cancer. Br. J. Cancer 122, 4-22. doi: 10.1038/s41416-019-0650-z

Lai, X. X., Li, G., Lin, B., and Yang, H. (2018). Interference of Notch 1 inhibits the proliferation and invasion of breast cancer cells: Involvement of the $\beta$-catenin signaling pathway. Mol. Med. Rep. 17, 2472-2478. doi: 10.3892/mmr.2017.8161

Lam, E. W.-F., Francis, R. E., and Petkovic, M. (2006). FOXO transcription factors: key regulators of cell fate. Biochem. Soc. Transac. 34, 722-726. doi: 10.1042/ BST0340722

Lasserre, R., Guo, X.-J., Conchonaud, F., Hamon, Y., Hawchar, O., Bernard, A.M., et al. (2008). Raft nanodomains contribute to Akt/PKB plasma membrane recruitment and activation. Nat. Chem. Biol. 4, 538-547. doi: 10.1038/ nchembio. 103

Laufs, U., Banach, M., Mancini, G. B. J., Gaudet, D., Bloedon, L. T., Sterling, L. R., et al. (2019). Efficacy and safety of bempedoic acid in patients with hypercholesterolemia and statin intolerance. J. Am. Heart Assoc. 8:e011662. doi: 10.1161/JAHA.118.011662

Lee, E. J., Yun, U.-J., Koo, K. H., Sung, J. Y., Shim, J., Ye, S.-K., et al. (2014). Downregulation of lipid raft-associated onco-proteins via cholesterol-dependent lipid raft internalization in docosahexaenoic acid-induced apoptosis. Biochim. Biophys. Acta 1841, 190-203. doi: 10.1016/j.bbalip.2013.10.006

Lee, J. V., Carrer, A., Shah, S., Snyder, N. W., Wei, S., Venneti, S., et al. (2014). Aktdependent metabolic reprogramming regulates tumor cell histone acetylation. Cell Metab. 20, 306-319. doi: 10.1016/j.cmet.2014.06.004

Lee, S. J., Hwang, J. W., Yim, H., Yim, H. J., Woo, S. U., Suh, S. J., et al. (2014). Synergistic effect of simvastatin plus NS398 on inhibition of proliferation and survival in hepatocellular carcinoma cell line. J. Gastroenterol. Hepatol. 29, 1299-1307. doi: 10.1111/jgh. 12503

Lee, J., Jung, K. H., Park, Y. S., Ahn, J. B., Shin, S. J., Im, S. A., et al. (2009). Simvastatin plus irinotecan, 5 -fluorouracil, and leucovorin (FOLFIRI) as firstline chemotherapy in metastatic colorectal patients: a multicenter phase II study. Cancer Chemother. Pharmacol. 64, 657-663. doi: 10.1007/s00280-0080913-5

Lee, T.-S., Chang, C.-C., Zhu, Y., and Shyy, J. Y.-J. (2004). Simvastatin induces heme oxygenase-1: a novel mechanism of vessel protection. Circulation 110, 1296-1302. doi: 10.1161/01.CIR.0000140694.67251.9C

Li, J., Xie, H., Ying, Y., Chen, H., Yan, H., He, L., et al. (2020). YTHDF2 mediates the mRNA degradation of the tumor suppressors to induce AKT phosphorylation in N6-methyladenosine-dependent way in prostate cancer. Mol. Cancer 19:152. doi: 10.1186/s12943-020-01267-6

Li, P.-S., Fu, Z.-Y., Zhang, Y.-Y., Zhang, J.-H., Xu, C.-Q., Ma, Y.-T., et al. (2014). The clathrin adaptor Numb regulates intestinal cholesterol absorption through dynamic interaction with NPC1L1. Nat. Med. 20, 80-86. doi: 10.1038/nm. 3417

Li, X., Wu, J. B., Li, Q., Shigemura, K., Chung, L. W. K., and Huang, W.-C. (2016). SREBP-2 promotes stem cell-like properties and metastasis by transcriptional activation of c-Myc in prostate cancer. Oncotarget 7, 12869-12884. doi: 10. 18632/oncotarget.7331

Liao, J. K. (2005). Clinical implications for statin pleiotropy. Curr. Opin. Lipidol. 16, 624-629. doi: 10.1097/01.mol.0000191913.16321.60

Liu, J., Eckert, M. A., Harada, B. T., Liu, S.-M., Lu, Z., Yu, K., et al. (2018). m6A mRNA methylation regulates AKT activity to promote the proliferation and tumorigenicity of endometrial cancer. Nat. Cell Biol. 20, 1074-1083. doi: 10.1038/s41556-018-0174-4

Liu, Z., Liu, X., Liu, S., and Cao, Q. (2018). Cholesterol promotes the migration and invasion of renal carcinoma cells by regulating the KLF5/miR-27a/FBXW7 pathway. Biochem. Biophys. Res. Commun. 502, 69-75. doi: 10.1016/j.bbrc.2018. 05.122

Ma, Q., Gao, Y., Xu, P., Li, K., Xu, X., Gao, J., et al. (2019). Atorvastatin inhibits breast cancer cells by downregulating PTEN/AKT pathway via promoting Ras Homolog Family Member B (RhoB). BioMed. Res. Int. 2019:3235021. doi: 10. $1155 / 2019 / 3235021$

Malanga, D., Scrima, M., De Marco, C., Fabiani, F., De Rosa, N., De Gisi, S., et al. (2008). Activating E17K mutation in the gene encoding the protein kinase AKT1 in a subset of squamous cell carcinoma of the lung. Cell Cycle 7, 665-669. doi: $10.4161 /$ cc.7.5.5485

Mandal, C. C. (2015). High cholesterol deteriorates bone health: new insights into molecular mechanisms. Front. Endocrinol. 6:165. doi: 10.3389/fendo.2015. 00165

Mandal, C. C., Das, F., Ganapathy, S., Harris, S. E., Choudhury, G. G., and Ghosh-Choudhury, N. (2016). Bone Morphogenetic Protein-2 (BMP-2) Activates NFATc1 transcription factor via an autoregulatory loop involving Smad/Akt/Ca2+ Signaling. J. Biol. Chem. 291, 1148-1161. doi: 10.1074/jbc. M115.668939

Mandal, C. C., Ghosh Choudhury, G., and Ghosh-Choudhury, N. (2009). Phosphatidylinositol 3 kinase/Akt signal relay cooperates with smad in bone morphogenetic protein-2-induced colony stimulating factor-1 (CSF-1) expression and osteoclast differentiation. Endocrinology 150, 4989-4998. doi: 10.1210/en.2009-0026

Mandal, C. C., Ghosh-Choudhury, N., Yoneda, T., Choudhury, G. G., and GhoshChoudhury, N. (2011). Simvastatin prevents skeletal metastasis of breast cancer by an antagonistic interplay between p53 and CD44. J. Biol. Chem. 286, 11314-11327. doi: 10.1074/jbc.M110.193714

Mandal, C. C., Ghosh-Choudhury, T., Dey, N., Choudhury, G. G., and GhoshChoudhury, N. (2012). miR-21 is targeted by omega-3 polyunsaturated fatty acid to regulate breast tumor CSF-1 expression. Carcinogenesis 33, 1897-1908. doi: $10.1093 /$ carcin/bgs198 
Mandal, C. C., Ghosh-Choudhury, T., Yoneda, T., Choudhury, G. G., and GhoshChoudhury, N. (2010). Fish oil prevents breast cancer cell metastasis to bone. Biochem. Biophys. Res. Commun. 402, 602-607. doi: 10.1016/j.bbrc.2010.10. 063

Mandal, C. C., and Rahman, M. M. (2014). Targeting intracellular cholesterol is a novel therapeutic strategy for cancer treatment. J. Cancer Sci. Ther. 6, 510-513. doi: 10.4172/1948-5956.1000316

Mantha, A. J., Hanson, J. E. L., Goss, G., Lagarde, A. E., Lorimer, I. A., and Dimitroulakos, J. (2005). Targeting the mevalonate pathway inhibits the function of the epidermal growth factor receptor. Clin. Cancer Res. 11, 23982407. doi: 10.1158/1078-0432.CCR-04-1951

Mehta, G. A., Parker, J. S., Silva, G. O., Hoadley, K. A., Perou, C. M., and Gatza, M. L. (2017). Amplification of SOX4 promotes PI3K/Akt signaling in human breast cancer. Breast Cancer Res. Treatment 162, 439-450. doi: 10.1007/s10549017-4139-2

Mendelsohn, J., and Baselga, J. (2000). The EGF receptor family as targets for cancer therapy. Oncogene 19, 6550-6565. doi: 10.1038/sj.onc.120 4082

Mistafa, O., and Stenius, U. (2009). Statins inhibit Akt/PKB signaling via P2X7 receptor in pancreatic cancer cells. Biochem. Pharmacol. 78, 1115-1126. doi: 10.1016/j.bcp.2009.06.016

Miura, K., Ohnishi, H., Morimoto, N., Minami, S., Ishioka, M., Watanabe, S., et al. (2019). Ezetimibe suppresses development of liver tumors by inhibiting angiogenesis in mice fed a high-fat diet. Cancer Sci. 110, 771-783. doi: 10.1111/ cas. 13902

Mohamedali, A., Lea, N. C., Feakins, R. M., Raj, K., Mufti, G. J., and Kocher, H. M. (2008). AKT1 (E17K) mutation in pancreatic cancer. Technol. Cancer Res. Treatment 7, 407-408. doi: 10.1177/153303460800700509

Mohammed, A., Qian, L., Janakiram, N. B., Lightfoot, S., Steele, V. E., and Rao, C. V. (2012). Atorvastatin delays progression of pancreatic lesions to carcinoma by regulating PI3/AKT signaling in p48Cre/+.LSL-KrasG12D/+ mice. Int. J. Cancer 131:1951. doi: 10.1002/ijc.27456

Montero, J., Morales, A., Llacuna, L., Lluis, J. M., Terrones, O., Basañez, G., et al. (2008). Mitochondrial cholesterol contributes to chemotherapy resistance in hepatocellular carcinoma. Cancer Res. 68, 5246-5256. doi: 10.1158/0008-5472. CAN-07-6161

Nagakubo, D., Taira, T., Kitaura, H., Ikeda, M., Tamai, K., Iguchi-Ariga, S. M., et al. (1997). DJ-1, a novel oncogene which transforms mouse NIH3T3 cells in cooperation with ras. Biochem. Biophys. Res. Commun. 231, 509-513. doi: 10.1006/bbrc. 1997.6132

Nakatani, K., Thompson, D. A., Barthel, A., Sakaue, H., Liu, W., Weigel, R. J., et al. (1999). Up-regulation of Akt3 in estrogen receptor-deficient breast cancers and androgen-independent prostate cancer lines. J. Biol. Chem. 274, 21528-21532. doi: $10.1074 /$ jbc. 274.31 .21528

Ng, S. S. W., Tsao, M. S., Chow, S., and Hedley, D. W. (2000). Inhibition of phosphatidylinositide 3-kinase enhances gemcitabine-induced apoptosis in human pancreatic cancer cells. Cancer Res. 60, 5451-5455.

Nguyen, T., Sherratt, P. J., and Pickett, C. B. (2003). Regulatory mechanisms controlling gene expression mediated by the antioxidant response element. Ann. Rev. Pharmacol. Toxicol. 43, 233-260. doi: 10.1146/annurev.pharmtox.43. 100901.140229

Nicholson, R. I., Gee, J. M., and Harper, M. E. (2001). EGFR and cancer prognosis. Eur. J. Cancer 37, S9-S15. doi: 10.1016/s0959-8049(01) 00231-3

Ohashi, H., Takagi, H., Oh, H., Suzuma, K., Suzuma, I., Miyamoto, N., et al. (2004). Phosphatidylinositol 3-kinase/Akt regulates angiotensin II-induced inhibition of apoptosis in microvascular endothelial cells by governing survivin expression and suppression of caspase-3 activity. Circ. Res. 94, 785-793. doi: 10.1161/01. RES.0000121103.03275.EC

Okudela, K., Hayashi, H., Ito, T., Yazawa, T., Suzuki, T., Nakane, Y., et al. (2004). $\mathrm{K}$-ras gene mutation enhances motility of immortalized airway cells and lung adenocarcinoma cells via Akt activation: possible contribution to non-invasive expansion of lung adenocarcinoma. Am. J. Pathol. 164, 91-100. doi: 10.1016/ S0002-9440(10)63100-8

Pä̈järvi, G., Roudier, E., Crisby, M., Högberg, J., and Stenius, U. (2005). HMGCoA reductase inhibitors, statins, induce phosphorylation of $\mathrm{Mdm} 2$ and attenuate the p53 response to DNA damage. FASEB J. 19, 476-478. doi: 10.1096/ fj.04-2745fje
Park, Y. H., Jung, H. H., Ahn, J. S., and Im, Y.-H. (2013). Statin induces inhibition of triple negative breast cancer (TNBC) cells via PI3K pathway. Biochem. Biophys. Res. Commun. 439, 275-279. doi: 10.1016/j.bbrc.2013.08.043

Patel, K. K., and Kashfi, K. (2021). Lipoproteins and cancer: The role of HDLC, LDL-C, and cholesterol-lowering drugs. Biochem. Pharmacol. 2021:114654. doi: 10.1016/j.bcp.2021.114654

PCUK. (2018). Types of pancreatic cancer. London: Pancreatic Cancer UK.

Phillips, S. A., and Thornalley, P. J. (1993). The formation of methylglyoxal from triose phosphates. Investigation using a specific assay for methylglyoxal. Eur. J. Biochem. 212, 101-105. doi: 10.1111/j.1432-1033.1993.tb17638.x

Porstmann, T., Santos, C. R., Griffiths, B., Cully, M., Wu, M., Leevers, S., et al. (2008). SREBP activity is regulated by mTORC1 and contributes to Aktdependent cell growth. Cell Metabol. 8, 224-236. doi: 10.1016/j.cmet.2008.07. 007

Pourshams, A., Sepanlou, S. G., Ikuta, K. S., Bisignano, C., Safiri, S., Roshandel, G., et al. (2019). The global, regional, and national burden of pancreatic cancer and its attributable risk factors in 195 countries and territories, 1990-2017: a systematic analysis for the Global Burden of Disease Study 2017. Lancet Gastroenterol. Hepatol. 4, 934-947. doi: 10.1016/S2468-1253(19)30347-4

Prendergast, G. C. (2001). Actin' up: RhoB in cancer and apoptosis. Nat. Rev. Cancer 1, 162-168. doi: 10.1038/35101096

Ramdass, B., Maliekal, T. T., Lakshmi, S., Rehman, M., Rema, P., Nair, P., et al. (2007). Coexpression of Notch1 and NF-kappaB signaling pathway components in human cervical cancer progression. Gynecol. Oncol. 104, 352-361. doi: 10. 1016/j.ygyno.2006.08.054

Raval, A. D., Thakker, D., Negi, H., Vyas, A., Kaur, H., and Salkini, M. W. (2016). Association between statins and clinical outcomes among men with prostate cancer: a systematic review and meta-analysis. Prostate Cancer Prostatic Dis. 19, 151-162. doi: 10.1038/pcan.2015.58

Reiner, Ž, Catapano, A. L., De Backer, G., Graham, I., Taskinen, M.-R., Wiklund, O., et al. (2011). ESC/EAS Guidelines for the management of dyslipidaemias: The task force for the management of dyslipidaemias of the European Society of Cardiology (ESC) and the European Atherosclerosis Society (EAS). Eur. Heart J. 32, 1769-1818. doi: 10.1093/eurheartj/ehr158

Revathidevi, S., and Munirajan, A. K. (2019). Akt in cancer: mediator and more. Semin. Cancer Biol. 59, 80-91. doi: 10.1016/j.semcancer.2019.06.002

Richard, J. P. (1993). Mechanism for the formation of methylglyoxal from triosephosphates. Biochem. Soc. Trans. 21, 549-553. doi: 10.1042/bst0210549

Rodriguez, A. C., Blanchard, Z., Maurer, K. A., and Gertz, J. (2019). Estrogen signaling in endometrial cancer: A key oncogenic pathway with several open questions. Hormones cancer 10, 51-63. doi: 10.1007/s12672-019-0358-9

Rogers, M., Kalra, S., Moukharskaya, J., Chakraborty, K., Niyazi, M., Krishnan, K., et al. (2015). Synergistic growth inhibition of PC3 prostate cancer cells with low-dose combinations of simvastatin and alendronate. Anticancer Res. 35, 1851-1859.

Roudier, E., Mistafa, O., and Stenius, U. (2006). Statins induce mammalian target of rapamycin (mTOR)-mediated inhibition of Akt signaling and sensitize p53deficient cells to cytostatic drugs. Mol. Cancer Ther. 5, 2706-2715. doi: 10.1158/ 1535-7163.MCT-06-0352

Rudling, M., Gåfvels, M., Parini, P., Gahrton, G., and Angelin, B. (1998). Lipoprotein receptors in acute myelogenous leukemia: failure to detect increased low-density lipoprotein (LDL) receptor numbers in cell membranes despite increased cellular LDL degradation. Am. J. Pathol. 153, 1923-1935. doi: 10.1016/S0002-9440(10)65706-9

Sangawa, A., Shintani, M., Yamao, N., and Kamoshida, S. (2014). Phosphorylation status of Akt and caspase-9 in gastric and colorectal carcinomas. Int. J. Clin. Exper. Pathol. 7, 3312-3317.

Sanli, T., Liu, C., Rashid, A., Hopmans, S. N., Tsiani, E., Schultz, C., et al. (2011). Lovastatin sensitizes lung cancer cells to ionizing radiation: modulation of molecular pathways of radioresistance and tumor suppression. J. Thoracic Oncol. 6, 439-450. doi: 10.1097/JTO.0b013e3182049d8b

Santarius, T., Bignell, G. R., Greenman, C. D., Widaa, S., Chen, L., Mahoney, C. L., et al. (2010). GLO1-A novel amplified gene in human cancer. Genes Chromosomes Cancer 49, 711-725. doi: 10.1002/gcc.20784

Saxton, R. A., and Sabatini, D. M. (2017). mTOR signaling in growth, metabolism, and disease. Cell 168, 960-976. doi: 10.1016/j.cell.2017.02.004

Schieber, M., and Chandel, N. S. (2014). ROS function in redox signaling and oxidative stress. Curr. Biol. 24, R453-R462. doi: 10.1016/j.cub.2014.03.034 
Schointuch, M. N., Gilliam, T. P., Stine, J. E., Han, X., Zhou, C., Gehrig, P. A., et al. (2014). Simvastatin, an HMG-CoA reductase inhibitor, exhibits antimetastatic and anti-tumorigenic effects in endometrial cancer. Gynecol. Oncol. 134, 346-355. doi: 10.1016/j.ygyno.2014.05.015

Schoonjans, K., Staels, B., and Auwerx, J. (1996). The peroxisome proliferator activated receptors (PPARS) and their effects on lipid metabolism and adipocyte differentiation. Biochim. Biophys. Acta 1302, 93-109. doi: 10.1016/00052760(96)00066-5

Sekine, Y., Nakayama, H., Miyazawa, Y., Kato, H., Furuya, Y., Arai, S., et al. (2018). Simvastatin in combination with meclofenamic acid inhibits the proliferation and migration of human prostate cancer PC-3 cells via an AKR1C3 mechanism. Oncol. Lett. 15, 3167-3172. doi: 10.3892/ol.2017.7721

Sharma, A., Bandyopadhayaya, S., Chowdhury, K., Sharma, T., Maheshwari, R., Das, A., et al. (2019). Metformin exhibited anticancer activity by lowering cellular cholesterol content in breast cancer cells. PloS One 14:e0209435. doi: 10.1371/journal.pone.0209435

Shi, L., and Tu, B. P. (2015). Acetyl-CoA and the regulation of metabolism: mechanisms and consequences. Curr. Opin. Cell Biol. 33, 125-131. doi: 10.1016/ j.ceb.2015.02.003

Shi, Y., Zhuang, Y., Zhang, J., Chen, M., and Wu, S. (2020). METTL14 inhibits hepatocellular carcinoma metastasis through regulating EGFR/PI3K/AKT signaling pathway in an m6a-dependent manner. Cancer Manag. Res. 12, 13173-13184. doi: 10.2147/CMAR.S286275

Shoji, K., Oda, K., Nakagawa, S., Hosokawa, S., Nagae, G., Uehara, Y., et al. (2009). The oncogenic mutation in the pleckstrin homology domain of AKT1 in endometrial carcinomas. Br. J. Cancer 101, 145-148. doi: 10.1038/sj.bjc. 6605109

Śliż, D., Marcinkiewicz, A., Olejniczak, D., Jankowski, P., Staniszewska, A., Mamcarz, A., et al. (2019). Hypercholesterolemia and prevention of cardiovascular diseases in the light of preventive medical examinations of employees in Poland. Int. J. Occup. Med. Environ. Health 32, 865-872. doi: 10.13075/ijomeh.1896.01446

Smalley, I., and Smalley, K. S. M. (2018). ERK Inhibition: A new front in the war against MAPK pathway-driven cancers? Cancer Discov. 8, 140-142. doi: 10.1158/2159-8290.CD-17-1355

Smith, B., and Land, H. (2012). Anticancer activity of the cholesterol exporter ABCA1 gene. Cell Rep. 2, 580-590. doi: 10.1016/j.celrep.2012.08.011

Song, G., Ouyang, G., and Bao, S. (2005). The activation of Akt/PKB signaling pathway and cell survival. J. Cell. Mol. Med. 9, 59-71. doi: 10.1111/j.1582-4934. 2005.tb00337.x

Song, M., Bode, A. M., Dong, Z., and Lee, M.-H. (2019). AKT as a therapeutic target for cancer. Cancer Res. 79, 1019-1031. doi: 10.1158/0008-5472.CAN-18-2738

Staal, S. P. (1987). Molecular cloning of the akt oncogene and its human homologues AKT1 and AKT2: amplification of AKT1 in a primary human gastric adenocarcinoma. Proc. Natl. Acad. Sci. U S A. 84, 5034-5037. doi: 10. 1073/pnas.84.14.5034

Stein, E. A., Lane, M., and Laskarzewski, P. (1998). Comparison of statins in hypertriglyceridemia. Am. J. Cardiol. 81, 66B-69B. doi: 10.1016/s0002-9149(98) 00041- 1

Sun, J., Zheng, Z., Chen, Q., Pan, Y., Quan, M., and Dai, Y. (2019). Fenofibrate potentiates chemosensitivity to human breast cancer cells by modulating apoptosis via AKT/NF-кB pathway. OncoTargets Ther. 12, 773-783. doi: 10. 2147/OTT.S191239

Sun, L.-T., Zhang, L.-Y., Shan, F.-Y., Shen, M.-H., and Ruan, S.-M. (2021). Jiedu Sangen decoction inhibits chemoresistance to 5-fluorouracil of colorectal cancer cells by suppressing glycolysis via PI3K/AKT/HIF-1 $\alpha$ signaling pathway. Chinese J. Nat. Med. 19, 143-152. doi: 10.1016/S1875-5364(21)60015-8

Tall, A. R., Wang, N., and Mucksavage, P. (2001). Is it time to modify the reverse cholesterol transport model? J. Clin. Invest. 108, 1273-1275. doi: 10.1172/ JCI14342

Thysell, E., Surowiec, I., Hörnberg, E., Crnalic, S., Widmark, A., Johansson, A. I., et al. (2010). Metabolomic characterization of human prostate cancer bone metastases reveals increased levels of cholesterol. PloS One 5:e14175. doi: 10. 1371/journal.pone.0014175

Toulany, M., Dittmann, K., Krüger, M., Baumann, M., and Rodemann, H. P. (2005). Radioresistance of K-Ras mutated human tumor cells is mediated through EGFR-dependent activation of PI3K-AKT pathway. Radiother. Oncol. 76, 143-150. doi: 10.1016/j.radonc.2005.06.024
Tzatsos, A., and Kandror, K. V. (2006). Nutrients suppress phosphatidylinositol 3-Kinase/Akt signaling via raptor-dependent mTOR-mediated insulin receptor substrate 1 phosphorylation. Mol. Cell. Biol. 26, 63-76. doi: 10.1128/MCB.26.1. 63-76.2006

Vassilev, B., Sihto, H., Li, S., Hölttä-Vuori, M., Ilola, J., Lundin, J., et al. (2015). Elevated levels of StAR-related lipid transfer protein 3 alter cholesterol balance and adhesiveness of breast cancer cells: potential mechanisms contributing to progression of HER2-positive breast cancers. Am. J. Pathol. 185, 987-1000. doi: 10.1016/j.ajpath.2014.12.018

Viglietto, G., Motti, M. L., Bruni, P., Melillo, R. M., D’Alessio, A., Califano, D., et al. (2002). Cytoplasmic relocalization and inhibition of the cyclin-dependent kinase inhibitor p27(Kip1) by PKB/Akt-mediated phosphorylation in breast cancer. Nat. Med. 8, 1136-1144. doi: 10.1038/nm762

Vilimanovich, U., Bosnjak, M., Bogdanovic, A., Markovic, I., Isakovic, A., KravicStevovic, T., et al. (2015). Statin-mediated inhibition of cholesterol synthesis induces cytoprotective autophagy in human leukemic cells. Eur. J. Pharmacol. 765, 415-428. doi: 10.1016/j.ejphar.2015.09.004

Vitols, S., Gahrton, G., Ost, A., and Peterson, C. (1984). Elevated low density lipoprotein receptor activity in leukemic cells with monocytic differentiation. Blood 63, 1186-1193.

Wang, J., Fu, L., Gu, F., and Ma, Y. (2011). Notch1 is involved in migration and invasion of human breast cancer cells. Oncol. Rep. 26, 1295-1303. doi: 10.3892/or.2011.1399

Wang, J.-J., Tian, Y., Xu, K.-L., Fu, R.-X., Niu, M.-S., and Zhao, K. (2018). [Statins Regulate the Proliferation and Apoptosis of T-ALL Cells through the Inhibition of Akt Pathway]. Zhongguo Shi Yan Xue Ye Xue Za Zhi 26, 359-367. doi: 10.7534/j.issn.1009-2137.2018.02.009

Wang, Q., Gao, G., Zhang, T., Yao, K., Chen, H., Park, M. H., et al. (2018). TRAF1 Is critical for regulating the BRAF/MEK/ERK pathway in non-small cell lung carcinogenesis. Cancer Res. 78, 3982-3994. doi: 10.1158/0008-5472.CAN-180429

Wang, T., Seah, S., Loh, X., Chan, C.-W., Hartman, M., Goh, B.-C., et al. (2016). Simvastatin-induced breast cancer cell death and deactivation of PI3K/Akt and MAPK/ERK signalling are reversed by metabolic products of the mevalonate pathway. Oncotarget 7:2532. doi: 10.18632/oncotarget.6304

Wang, Y., Liu, C., and Hu, L. (2019). Cholesterol regulates cell proliferation and apoptosis of colorectal cancer by modulating miR-33a-PIM3 pathway. Biochem. Biophys. Res. Commun. 511, 685-692. doi: 10.1016/j.bbrc.2019.02.123

Wang, Z.-S., Huang, H.-R., Zhang, L.-Y., Kim, S., He, Y., Li, D.-L., et al. (2017). Mechanistic study of inhibitory effects of metformin and atorvastatin in combination on prostate cancer cells in Vitro and in Vivo. Biol. Pharm. Bull. 40, 1247-1254. doi: 10.1248/bpb.b17-00077

Ward, P. S., and Thompson, C. B. (2012). Signaling in control of cell growth and metabolism. Cold Spring Harbor Perspec. Biol. 4:a006783. doi: 10.1101/ cshperspect.a006783

WCRF (2018). Pancreatic Cancer Statistics [Online]. World Cancer Research Fund. Available online at: https://www.wcrf.org/dietandcancer/pancreatic-cancerstatistics/ (Accessed March 17, 2021).

Wellen, K. E., Hatzivassiliou, G., Sachdeva, U. M., Bui, T. V., Cross, J. R., and Thompson, C. B. (2009). ATP-citrate lyase links cellular metabolism to histone acetylation. Science 324, 1076-1080. doi: 10.1126/science.1164097

White, C. P. (1909). On the occurrence of crystals in tumours. J. Pathol. Bacteriol. 13, 3-10. doi: 10.1002/path.1700130103

World Health Organisation. (2021). WHO Mean cholesterol. Available Online at: https://www.who.int/gho/ncd/risk_factors/cholesterol_mean_text/en/ [Accessed 3 April 2021]

Wu, H., Jiang, H., Lu, D., Xiong, Y., Qu, C., Zhou, D., et al. (2009). Effect of simvastatin on glioma cell proliferation, migration, and apoptosis. Neurosurgery 65, 1087-1096. doi: 10.1227/01.NEU.0000360130.52812.1D

Wu, Z., Niu, T., and Xiao, W. (2019). Uev1A promotes breast cancer cell survival and chemoresistance through the AKT-FOXO1-BIM pathway. Cancer Cell Int. 19:331. doi: 10.1186/s12935-019-1050-4

Xiao, H., Zhang, Q., Lin, Y., Reddy, B. S., and Yang, C. S. (2008). Combination of atorvastatin and celecoxib synergistically induces cell cycle arrest and apoptosis in colon cancer cells. Int. J. Cancer 122, 2115-2124. doi: 10.1002/ijc.23315

Xu, D., Wang, Z., Xia, Y., Shao, F., Xia, W., Wei, Y., et al. (2020). The gluconeogenic enzyme PCK1 phosphorylates INSIG1/2 for lipogenesis. Nature 580, 530-535. doi: $10.1038 / \mathrm{s} 41586-020-2183-2$ 
Yamasaki, D., Kawabe, N., Nakamura, H., Tachibana, K., Ishimoto, K., Tanaka, T., et al. (2011). Fenofibrate suppresses growth of the human hepatocellular carcinoma cell via PPAR $\alpha$-independent mechanisms. Eur. J. Cell Biol. 90, 657-664. doi: 10.1016/j.ejcb.2011.02.005

Yue, S., Li, J., Lee, S.-Y., Lee, H. J., Shao, T., Song, B., et al. (2014). Cholesteryl ester accumulation induced by PTEN loss and PI3K/AKT activation underlies human prostate cancer aggressiveness. Cell Metabol. 19, 393-406. doi: 10.1016/ j.cmet.2014.01.019

Yun, S. M., Yoon, K., Lee, S., Kim, E., Kong, S.-H., Choe, J., et al. (2014). PPP1R1BSTARD3 chimeric fusion transcript in human gastric cancer promotes tumorigenesis through activation of PI3K/AKT signaling. Oncogene 33, 53415347. doi: 10.1038/onc.2013.472

Zeng, M., Gu, W.-Y., Jiang, T.-X., Chen, Z.-X., Qiu, G.-Q., Li, M., et al. (2012). [Effects of simvastatin on PI3K/AKT signaling pathway in human acute monocytic leukemia cell line SHI-1]. Zhongguo Shi Yan Xue Ye Xue Za Zhi 20, $268-272$.

Zhang, H., and Hu, N. (2018). Telomerase reverse transcriptase induced thyroid carcinoma cell proliferation through PTEN/AKT signaling pathway. Mol. Med. Rep. 18, 1345-1352. doi: 10.3892/mmr.2018.9119

Zhang, T., Bai, R., Wang, Q., Wang, K., Li, X., Liu, K., et al. (2019). Fluvastatin inhibits HMG-CoA reductase and prevents non-small cell lung carcinogenesis. Cancer Prevent. Res. 12, 837-848. doi: 10.1158/1940-6207.CAPR-19-0211

Zhao, T. T., Le Francois, B. G., Goss, G., Ding, K., Bradbury, P. A., and Dimitroulakos, J. (2010). Lovastatin inhibits EGFR dimerization and AKT activation in squamous cell carcinoma cells: potential regulation by targeting rho proteins. Oncogene 29, 4682-4692. doi: 10.1038/onc.2010.219

Zhao, Y., Shen, S., Guo, J., Chen, H., Greenblatt, D. Y., Kleeff, J., et al. (2006). Mitogen-activated protein kinases and chemoresistance in pancreatic cancer cells. J. Surg. Res. 136, 325-335. doi: 10.1016/j.jss.2006.06.031
Zhou, B. P., Liao, Y., Xia, W., Spohn, B., Lee, M. H., and Hung, M. C. (2001). Cytoplasmic localization of p21Cip1/WAF1 by Akt-induced phosphorylation in HER-2/neu-overexpressing cells. Nat. Cell Biol. 3, 245-252. doi: 10.1038/ 35060032

Zhuang, L., Lin, J., Lu, M. L., Solomon, K. R., and Freeman, M. R. (2002). Cholesterol-rich lipid rafts mediate Akt-regulated survival in prostate cancer cells. Cancer Res. 62, 2227-2231.

Zilberman, D. E., Cohen, Y., Amariglio, N., Fridman, E., Ramon, J., and Rechavi, G. (2009). AKT1 E17 K pleckstrin homology domain mutation in urothelial carcinoma. Cancer Genet. Cytogenet. 191, 34-37. doi: 10.1016/j.cancergencyto. 2009.01.009

Conflict of Interest: The authors declare that the research was conducted in the absence of any commercial or financial relationships that could be construed as a potential conflict of interest.

Publisher's Note: All claims expressed in this article are solely those of the authors and do not necessarily represent those of their affiliated organizations, or those of the publisher, the editors and the reviewers. Any product that may be evaluated in this article, or claim that may be made by its manufacturer, is not guaranteed or endorsed by the publisher.

Copyright (c) 2021 Kumar and Mandal. This is an open-access article distributed under the terms of the Creative Commons Attribution License (CC BY). The use, distribution or reproduction in other forums is permitted, provided the original author(s) and the copyright owner(s) are credited and that the original publication in this journal is cited, in accordance with accepted academic practice. No use, distribution or reproduction is permitted which does not comply with these terms. 